\author{
Naum Trajanovski \\ Graduate School for Social Research, Polish Academy of Sciences \\ Warsaw \\ https://orcid.org/0000-0001-9686-7861 \\ trajanovskinaum@gmail.com
}

\title{
Zbor imaat graǵanite: \\ The First Sociological Study, the Polish Sociological Expert Aid to Macedonia in the Mid-1960s and the Post-Earthquake History of Interethnic Relations in Skopje
}

\begin{abstract}
On the early morning of 26 July 1963, a calamitous earthquake struck the Macedonian capital of Skopje, taking the lives of 1,070 people and destroying more than two-thirds of the urban fabric. The politically non-aligned Yugoslav government immediately issued a call for help for the earthquake-torn city, which was picked up by more than eighty states across the globe, as well as the United Nations and other international organizations. The domestic authorities, in turn, sought to reimagine post-disaster Skopje as a "City of Solidarity," a symbol of the trans-bloc cooperation, and an "Open City" - one open to domestic and intrafederal migrations and the epitome of the trans-Yugoslav state-building slogan of "brotherhood and unity." However, the mounting interethnic tensions in the 1980s, the Yugoslav dissolution, and the 2001 insurgency dramatically shifted the public optics over the post-earthquake urban reconstruction and demographic politics - a narrative which found a particular stronghold in the memory politics of post-2001 Macedonia.
\end{abstract}

This is an Open Access article distributed under the terms of the Creative Commons Attribution 3.0 PL License (creativecommons.org/licenses/by/3.0/pl/), which permits redistribution, commercial and non-commercial, provided that the article is properly cited. (C) The Author(s), 2021.

Publisher: Institute of Slavic Studies, Polish Academy of Sciences

Editor-in-chief: Jolanta Sujecka

Conception and academic editing: Maciej Falski, Linda Kovárová 
The present paper discusses one overlooked episode from the post-earthquake reconstruction of Skopje: from December 1964 to April 1965, the first ever largescale sociological survey was conducted among Skopjans as part of the Polish expert aid and the preparations for the UN-sponsored Skopje Urban Project. Although the published study contained an exclusive portrayal of the economic and demographic features of the local households and revealed some of the major interethnic issues in the city, it never received proper treatment by the authorities and - up to the Yugoslav dissolution - in the scholarship. Thus, in order to present the major outcomes of this cross-national endeavor, I reconstruct the prehistory, the fieldwork and the immediate results of the survey by triangulating a set of archival materials, semi-structured interviews with its Polish and Macedonian conveners, and secondary literature on Skopje's urban reconstruction. Finally, I argue that the survey - its realization, results and aftermath - can be read as a key to a better understanding of the post-earthquake history of Skopje and the interethnic relations in the city.

Keywords: Skopje, 1963 Skopje earthquake, urban sociology, urban planning, interethnic relations, knowledge-transfers.

\section{Introduction $^{1}$}

$\bigcirc_{s}^{\mathrm{n}}$ n the early morning of 26 July 1963, a calamitous earthquake struck the Macedonian capital of Skopje. ${ }^{2}$ The brief 17-second tremor entirely destroyed more than two-thirds of the urban fabric - 50 objects of public use and approximately 2,000 housing units - and was the direct cause of the deaths of 1,070 people. ${ }^{3}$ The politically non-aligned

1 I would like to thank all my informants for their cooperation; Kinga Nettmann-Multanowska, Pavel Veljanovski and Bojan Blaževski for their insights on the so-called Skopje Team (Pol. zespół skopijski); and Emilija Crvenkovska, Jovan Ivanovski, Emilija Simoska and Petar Todorov for sharing their expertise and recollections. I would also like to thank Zoja Bogdanovska for the tremendous help with the archival research at the Museum of the City of Skopje, and Keith Horechka for proofreading the final version of the text. All the translations in the text are mine, unless otherwise indicated. The transliteration to Latin script is in accordance with ISO 9 (1968) system. This research was supported by the National Science Centre, Poland under the PRELUDIUM 17 grant scheme, contract number 2019/33/N/HS3/02209.

2 The state name, as well as the subsequent ethnic and national adjectives, is brought in accordance with the 2018 Greco-Macedonian Agreement. The author uses the former constitutional name of Republic of Macedonia referring to the time-period from 1991 to the official ratification of the Agreement (February 2019), as well as the erstwhile state-name Socialist Republic of Macedonia (for the time period of 1963 to 1991), according to the official statement of the North Macedonia's and the Greek governments on the non-retroactiveness of the new state-name.

3 Out of the 1,070 deceased, 46 were identified as foreign nationals and 43 remained unidentified (more in: 26 juli 1963, 1963). 
Yugoslav government immediately issued a call for help for its third largest city and the erstwhile southernmost federal capital. The call was initially picked up by the other Yugoslav republics, followed by more than eighty states across the globe and a high number of international organizations, all providing help to Skopje and Skopjans in the aftermath of the catastrophe; an episode of human solidarity which many contemporaries depicted as "unprecedented." ${ }^{4}$ The emerging role of the United Nations (UN) as a systemizing agent of the post-earthquake aid and donations to Skopje turned out to be crucial to the fate of the city. The UN endorsed the political decision to rebuild the city just days after the earthquake, while later on, in October 1963, the organization unanimously passed a resolution to support the Yugoslav government in the post-earthquake reconstruction of Skopje. ${ }^{5}$ The urban reconstruction under the auspices of the UN's Special Fund was thus projected to be led by a team of prominent international architects and urban planners, and to last up until the early 1980s. This also facilitated the Yugoslav and Macedonian authorities' initiative to reimagine the Macedonian capital as a "City of Solidarity" - a symbol of trans-bloc cooperation and a strategic move "made necessary by the Cold War context" (Tolic, 2019, p. 40) - and an "Open City": open to domestic and intra-federal migrations, "a symbol of the brotherhood and unity of our [Yugoslav] peoples and the international solidarity."

4 First to arrive in the earthquake-torn city were the citizens of the neighboring Macedonian towns and villages, but also those from Serbia and Kosovo. The Yugoslav People's Army was among the first to be mobilized for the rescue operations in the wake of the earthquake. The relief operation lasted up to October 1963, with the first ten post-earthquake days being the most intensive (Madik, 1963). The process was conducted parallel to the evacuation of women and children and the provision of tent shelters (more on the immediate post-earthquake disaster management period in: Fisher, 1964).

5 An extensive account of UN's involvement in post-1963 Skopje can be found in Skopje Resurgent: The Story of a United Nations Special Fund Town Planning Project, a 400-page study published in 1970, authored by Derek Senior - a British freelance expert on town planning and a former member of the Royal Commission on Local Government in England - and the so-called "Yellow Books" (Lozanovska \& Martek, 2019), a set of 22 reports of the UNcoordinated activities in Skopje, published in Macedonian, Serbo-Croatian and English in the mid and late 1960s. Yugoslavia was also one of the founding members of the UN and an original signatory of the UN Charter at the UN Conference on International Organizations (Spaskovska, 2020, p. 143). See Trajanovski, 2021b for a diachronic overview of the development of the solidarity cultural memory trope in the aftermath of the earthquake.

6 City of Skopje Archive (CSA), Skopje: Dnevni Jugoslovenski Operativno-Informativni Bilten o Obnovi i Izgradnju, Sociološki aspekti novog generalnog urbanističkog plana Skopja, 29 May 1964, 1-6. The "Open City" concept was further relegitimized with the winning plan in the separate competition for the reconstruction of the Skopje city center. Even though in July 1965 the jury announced no clear winner and divided the first prize between the Japanese starchitect Kenzo Tange-led team (60\%) and the Croats Radovan Miščević and Fedor Wenzler (40\%), the 
The present paper is focused on one overlooked episode from the postearthquake reconstruction of Skopje which, as I will argue, is immensely interesting in light of the post-1963 history of interethnic relations in the city. From December 1964 to April 1965, the first ever large-scale sociological study was conducted among Skopjans as part of the Polish expert aid to post-earthquake Skopje and the preparations for the UN-sponsored Skopje Urban Project. The social survey (Mac. socijalen pregled) was coordinated by a team of four Polish and seven Macedonian experts, engaged eighty specially trained local interviewers, and managed to get to 4,006 local Skopjans and their families to share information on their current living and housing conditions and their preferences in this respect, and to share their ideas for the future urban development with the research team. The study contained an exclusive portrayal of the economic and demographic features of the local households, and revealed some of the major interethnic issues of post-earthquake Skopje; it was also immensely important for the professional careers of the lead researchers. However, it never received proper treatment from the authorities or, up to 1991, from scholars.

In this paper I will discuss the development of this pioneering study by reconstructing its prehistory, fieldwork and immediate results, as well as its treatment in the public and scholarly discourses ever since. For the purposes of this study, I will triangulate a set of archival materials, semistructured interviews, and secondary literature. ${ }^{7}$ I also approach the social survey data along the methodology of "secondary analysis of qualitative data," the premise being that reusage of data generated by previous projects can reveal "methodological and substantive insights" (Bishop \& KuulaLuumi, 2017, p. 1). The paper starts with mapping the critical contexts

responsibility to devise a new plan remained within the Skopje City Council's Institute of Town Planning and Architecture (ITPA, see note 14 below); the major features of the Tange's initial plan - an open, metabolist structure with an ever-growing tendency - marked the post-earthquake reconstruction of Skopje (more in Lozanovska, 2012).

7 I conducted interviews with four members of the Polish expert team working on the Skopje Urban Project (Wojciech Suchorzewski, Stanisław Furman, Bogdan Wyporek, Zbigniew Galperyn), two members of the social survey team (Zbigniew Sufin and Mimoza Nestorova-Tomić), as well as the two siblings of Zygmunt Pióro (Małgorzata and Tadeusz). I was researching archival materials at the City of Skopje Archive, the Archive of the Museum of the City of Skopje, the Archive of the Institute for Sociological, Political and Juridical Research, the libraries of the Macedonian Academy of Sciences, the Faculty of Architecture - Skopje, the National and University Library "Sv. Kliment Ohridski" - Skopje, and the City library "Braḱa Miladinovci" - Skopje. I also consulted the relevant materials at the Archive of the Polish Ministry of Foreign Affairs, the Archive of the Institute of Philosophy and Sociology, Polish Academy of Sciences, and the National Library in Warsaw; as well as Vera and Donald Blinken Archives in Budapest and the Serbian State Archive in Belgrade. The interviews and the archival materials are quoted in footnotes. 
of pre-1963 Skopje and Macedonia, and the dominant discourses on sociological research in urban planning in the 1960s. This is followed by overview of the preparations for the Skopje Urban Project and a discussion of the development and realization of the social survey, as well as the various interdisciplinary references to it later on, in chronological order. Finally, I argue that the survey - its realization, results and effects - can be read as a key to a better understanding of the post-earthquake history of Skopje and the interethnic relations in the city.

\section{Contexts}

The end of World War II and the formation of Second Yugoslavia paved the way for the "finalization" of Macedonian state- and nationbuilding (Spaskovska, 2011, p. 2). This process manifested not only in the establishment of key national institutions - inter alia, the codification of the standard Macedonian language (1945) and the inauguration of the Macedonian National Theater (1945) and Skopje University (1946) - but also in political recognition of the rights of ethnic minority groups. Hence, building upon the ill-fated 1903 Ilinden Uprising, the wartime manifesto Proclamations to the Peoples and Nationalities in Macedonia (Mac. Proglasi za narodite i narodnostite vo Makedonija) and the Yugoslav Partisans' "brotherhood and unity" slogan, the first Macedonian postwar government postulated self-determination as a leading principle of the post-war Macedonian state. In practice, it translated as recognition of groupist rights related to education, language use, freedom of speech and assembly, and cultural development. The 1948 Tito-Stalin split, the advancement of workers' self-management as of the 1950s and, especially, the removal of Aleksandar Ranković - one of the main proponents of Yugoslav centralism - from the political mainstream in the mid-1960s, led to a new redefinition and improvement of the status of the ethnic communities in Yugoslavia. In the scholarly literature, the 1960s are noted as the period of definite abandonment of integral Yugoslavism, i.e. the political support for the supranational Yugoslav ethnic identity, and a general acceptance of organic Yugoslavism, i.e. the initiative for stimulating the separate Yugoslav ethnic and national identities (for an overview, see Ramet, 1984). Organic Yugoslavism was solidified in the 1963 Yugoslav Constitution and the reimagination of the Yugoslav federation as a "shelter" for the particular ethnic and national identities. In the words of Adamson and Jović, "no one was a 'minority" in Yugoslavia after 1963 (Adamson \& Jović, 2004, p. 296). 
One other event from 1960s Macedonia is significant for our discussion: drawing upon the breakthrough of younger political leaders on the federal level, the shifts in the Macedonian party and state structures were completed with the installation of - what would later be depicted as - a "liberal" cohort of politicians to power in 1963 (more in Radičeski, 2013). The major credo of this generation of politicians was further development of Macedonia as a "civilized European nation" (Popovski, 1968) - an initiative that resulted in the formation of the Macedonian Academy of Sciences and Arts (1967) and the proclamation of autocephality of the Macedonian Orthodox Church (1967) - which also meant refocusing of the political optics towards minority rights and the interethnic relations in the state. Thus, the new elite sought to overcome the post-war cultural autonomy model of ethnic rights by fostering the participation of the minorities in the state institutions and in Macedonian society. "Macedonia should be built as a state community not only of the Macedonians, but also of the Turks and Albanians," wrote Krste Crvenkovski, the leading political figure of the period, in 1970 (Crvenkovski, 1970; see also Filip \&Crvenkovski, 1993; Milosavlevski \& Tomovski, 1997). This initiativeindeed led to a general growth of the number of minority members participating in the local and national state institutions (more in Anakioski, 1967), but also to constitutional amendments which allowed equal status (Mac. ramnopravnost) of the languages, the usage of flags in several Macedonian municipalities (Čičak, 1969), and the publishing of Macedonian-Albanian and Macedonian-Turkish dictionaries (Elimov, 1969). Ultimately, it also led towards a full endorsement of the "Open City" politics in the wake of the earthquake: even though the rapid industrialization had tripled the city population before 1963 - from 66,893 in 1937 to approximately 213,000, thus making it the third largest Yugoslav city in the early 1960s (Matkovski, 1964) - Crvenkovski viewed the influx to Skopje as a "positive instrument for rapprochement of the peoples" ("Krste Crvenkovski," 1966).

The population influxes to the urban areas were not a novelty in postwar Yugoslavia, as the state was meeting those challenges with massive investments in functionalist housing complexes (e.g. plans for New Belgrade, more in Le Normand, 2008; and New Zagreb, more in Galjer, 2019). ${ }^{8}$ The 1963 Skopje earthquake, however, occurred at a critical moment both for Yugoslav and international urban planning. Post-earthquake Skopje was undoubtedly built upon the organizational network of the International Congress of Modern Architecture (CIAM; see Lozanovska \& Martek, 2019; Martek \& Lozanovska, 2018; Spaskovska, 2020), which

8 As a direct result of migratory movements to urban areas, for instance, the urban population in Yugoslavia grew by 170\% from 1953 to 1961 (Ginić, 1963, in: Bojić, 2019, p. 2).

6/41 COLLoquia 6 Humanistica 
although disbanded in 1959, still informed the UN-led reconstruction of the city. The agency of Ernest Weissmann - an architect of Croat Jewish origins; a CIAM member who prepared the conference for the CIAM's manifesto: the 1933 Athens Charter; a UN officer at ECOSOC; and an intermediary between the international institutions and the Yugoslav government during the post-earthquake reconstruction - was critical in these regards, as it was him who saw the reconstruction of post-earthquake Skopje as a platform for a "debate among planners in spite of and against Cold War polarization" (Tolic, 2017, p. 195). Eventually, this openness to new solutions in the urban reconstruction of Skopje came at the peak of the criticism over some of the main postulates of CIAM's modernism in the 1960s. ${ }^{9}$ One of the most relevant targets here was CIAM's clearcut division of the urbanist discourse between architecture and planning, and the attendant critical stance led towards an integration of a broader spectrum of disciplines - such as sociology, psychology and graphics in the post-CIAM urban planning (Lozanovska \& Martek, 2019). More precisely, this endorsement of interdisciplinarity fostered the trend of using social surveys in urban planning as means of identifying the pressing needs of society (Deipenbrock et al., 2010, p. 92). Social surveys were also expected to provide data on cultural preferences and symbolic affiliations of citizens; another contrapuntal thesis to Athens Charter's negligence of cultural particularities. ${ }^{10}$ In Skopje, a neat illustration of this novel inclination to cultural identities was Tange's reading of the "castle rampart" and its reference in the City Wall - one of his two emblematic projects in the post-earthquake city (Tange, 1971, pp. 47-48).

Although with no experience in social surveying for urban planning purposes, the post-war Yugoslav sociology had unarguably produced a vast set of materials in the bordering disciplines of migration studies, rural sociology, sociology of culture and ethnic identities and, as of the late 1950s, urban sociology (Kostic, 1983; for an overview, see Flere, 1994; Lazić, 2011; Duller, 2018). ${ }^{11}$ This breakthrough occurred in

\footnotetext{
9 According to Mumford, in the course of the 1960s "CIAM became associated with a kind of technocratic architectural idiocy, insensitive to climate, local culture or human scale" (Mumford, 1992, p. 413).

10 It is interesting to note here Jane Jacobs' concept of "Open City" - a space which facilitates unexpected encounters, promotes urban life and serves social needs - developed in the early 1960s as an argument against Le Corbusier's Plan Voisin, which, according to Jacobs, eliminates public life and lacks a human scale (more in Sennett, 2006). Le Corbusier's ideas were the ideological basis for CIAM. Although Jacobs' ideas and wording might suggest certain influence over the Skopje Urban Project, there is no such link or cross-reference between the two in the literature consulted for this paper.

${ }_{11}$ The agencies of Miroslav Živković and Zdravko Mlinar are of particular importance for
} 
a relatively short time span as institutionalized sociology was reestablished in Yugoslavia only in the mid-1950s, a common process across socialist Central and Eastern Europe after Stalin's death and the break with the dogmatic Marxism that saw sociology as a bourgeois legacy (more in: Brunnbauer et al., 2011; Vořŕšek, 2012). Moreover, Yugoslavia’s “increased visibility on the global stage" (Spaskovska, 2020, p. 143) in the 1950s and the 1960s was also capitalized on the emerging generation of post-war Yugoslav sociologists: as of the 1960s, Yugoslavia provided a platform for international sociological exchanges in various research fields. ${ }^{12}$ The sociological boom also occurred in socialist Macedonia. The major research foci of the early 1960s Macedonian sociology mirrored the main social trends of the day: rural-urban migration, rapid industrialization and labor conditions (see e.g. Uzunov, 1961). ${ }^{13}$ As of the mid-1960s, the state and corporate support to sociological research (for instance, the industry sector sponsored more than a third of the scientific research from 1965 to 1982 in socialist Macedonia; more in Sostojbi i ocenki, 1987, p. 9) resulted, initially, in formation of several "sociological circles" in Skopje and, ultimately, in the foundation of the Institute for Sociological, Political and Juridical Research (ISPJ) in 1966. ${ }^{14}$ The institutional infrastructure of ISPJ thus

the development of the Yugoslav urban sociology from the 1960s to the collapse of Yugoslavia: Živković worked on the various aspects of housing and social segregation in the 1960s before shifting his research interest to the "sociological aspects of urban planning" in the 1970s (more in Živković, 1975, 1977, 1979, 1980; see Archer, 2018, for an overview of his early career), while Mlinar was one of the pioneers of spatial sociology both in Yugoslavia and internationally (see, for instance, Mlinar, 1979).

12 The so-called Praxis group is one of the most prominent examples here: linked with the journal Praxis (issued in 1964-1974) and the annual meetings in Korčula, the group of Yugoslav scholars were critical of the state's sociopolitical reality - their motto being "relentless critique of all the existing conditions" - and promoted the Yugoslav self-management via reading early Marx, followers of the Frankfurt School and other European "Marxist revisionists" (for an overview, see Olujić \& Stojaković, 2012; Sher, 1977; for the Polish-Yugoslav exchanges, see BielińskaKowalewska, 2012). Praxis affiliates also articulated a philosophical criticism of the Yugoslav urban planning in the late 1960s and the early 1970s (for an overview, see Padgett, 1973; see also: Le Normand, 2014, pp. 189-212, for a general overview of the social scientific discourses on urban planning in the course of the Yugoslav 1960s)

13 The case of Boris Arsov - a Sorbonne graduate who published pioneering works in rural sociology and ethnography in the interwar period - is particularly interesting here, as it shows that the social scientific interest in Macedonian rural areas can be traced back to the 1930s. A similar case is that of Józef Obrębski, which will be touched upon later in the text. Arsov's legacy was rediscovered only in post-Yugoslav Macedonia: even though he was a delegate at the first Macedonian provisional government in 1944, his sociological activities were forbidden up to 1954, the year he died (more in Georgievski \& Gurovska, 2003; Georgievski, 2013, pp. 76-90).

14 Three of them being the group around Jakim Sinadinovski (a professor of ethnology at the Faculty of Natural Sciences and Mathematics), the group around Slavko Milosavlevski (a 
fostered not only better articulation of the prevailing sociological debates in Macedonia - on, inter alia, rural sociology (see Kostovski, 1975), labor migrations and housing (Ivanoski, 1966; Jovanovski, 1976; Uzunov, 1975), and, as of the 1980s, ethnic minority identities and interethnic relations (for an overview, see Popovska, 2015) - but it also stimulated intra-Yugoslav cooperation; an example here is the Macedonian-Slovenian cross-national sociological survey in the 1970s on the social stratification in Macedonia and Slovenia, that is, the least and the most developed Yugoslav republics (Lazić, 2011, p. 94) ${ }^{15}$ However, even though Jakim Sinadinovski (see note 14) was considered for participation in the social survey team, none of the emerging Macedonian sociologists were offered positions in the end. The reasons for this will be touched upon in the following sections.

\section{The Preparations}

The general idea for a Skopje social survey was ultimately a result of the post-earthquake disaster management and, especially, of the UN's takeover of the Skopje urban planning process in October 1963. However, even before the official announcement of the social survey, the local authorities commissioned studies and research on the demographic and economic features of Skopje's population as a basis for crafting urban policies in the wake of the disaster. Almost immediately after July 1963, the Skopje City Council's Institute of Town Planning and Architecture (ITPA) started publicizing recommendations for locations of the new temporary housing and urban settlements, drawing upon the 1961 population census and the earlier planning documents. By the end of the year, the ITPA, alongside se-

docent at the Faculty of Law and a prominent member of the "liberal faction" of the Macedonian League of Communists; more on the formation of ISPJ in "Institut za sociološki i pravni isleduvanja," 1964), and the group affiliated with the Faculty of Economy in Skopje. One such endeavour by the last group was the large-scale research project on "reproductive behaviors" of the rural population in less developed Macedonian areas from the 1980s (more in Josifovski et al., 1988).

15 As of the mid-1970s, the ISPJ started publishing annual public opinion polls and analyses (the scope and the rationale behind the polls are available in the first issue: Popovski, 1976). On a different note, the first ever organized research on the Albanian population in Macedonia was conducted in 1940 and 1941, as part of a trans-Yugoslav research project, by the Institute of Geography at the Faculty of Philosophy in Skopje. The results of this study were lost in the war as per Jovan Trifunovski, a geographer and a member of the research team in the early 1940s. Trifunovski's anthropological and ethnographical research of the Albanian population in Macedonia was published posthumously in 2019, although the manuscript, as per the author, was finished in 1983. The author hinted at the "changing conditions" as one possible reason for not publishing the manuscript in the 1980s (Trifunovski, 2019, p. 6). 
veral other local institutions and the Union of Societies of Urban Planners of Yugoslavia, managed to issue a number of "preparatory-programmatic works" for the forthcoming urban study and spatial design of the Skopje region. ${ }^{16}$ This entire process was monitored by two UN-affiliated planners, Maurice Rotival (France) and Anatolij N. Rimsha (USSR), who visited Skopje "in the first months after the catastrophe" to "discuss planning problems with the local authorities" (Senior, 1970, p. 73). ${ }^{17}$ The planners' visit to Skopje overlapped with yet another UN-sponsored visit to the city, by a group of four earthquake engineers who concluded, just a few months after the disaster, that there was no need to consider a change of the current city location due to seismological concerns. ${ }^{18}$

The international expert group - consisting of a Frenchman (J. Despeyroux), a Briton (N. N. Ambraseys), a Czechoslovak (A. Zátopek) and a Soviet Russian (A. A. Sorskiǐ) - alongside the similar lineup of the aforementioned urban planners, best reflects the UN's politics of "parts and counterparts" in Skopje's post-earthquake reconstruction, that is, the strategy of maintaining balance between the "conflicting political lineups" of the day by involving them all in the reconstruction process (Tolic, 2019 , p. 45). This approach reappeared, as we shall see in this section, in the outline plan project and, subsequently, the social survey. Moreover, the preparatory work and the social survey's fieldwork also reaffirmed and set the contextual boundaries of what Ljubica Spaskovska observes as a "hybrid modernity" of Skopje's reconstruction (Spaskovska, 2020, p. 139): a tendency to twist "Western concepts and idioms of technological achievement, planning and construction" to fit the local contexts of postcolonial and post-revolutionary nationalisms. This point will be discussed in the next section.

16 ITPA - a new state office with a mission to coordinate the reconstruction and, in the later phases, the "social survey, master plan, housing, traffic and transportations" (Davis, 1975, p. 661) - cooperated with the leading economic, geologic, water management, biologic, and forestry institutes of SR Macedonia, as well as SR Serbia's communal hygiene and health protection institutes, the federal health protection institute, and the military-geographic institute of the Socialist Federal Republic of Yugoslavia for the work on these documents. More in CSA, Skopje: Dnevni Jugoslovenski Operativno-Informativni Bilten o Obnovi i Izgradnju, O dosadašnjem radu na urbanističkoj studiji i prostornom konceptu Skopja, 15 September 1964, 1-5.

17 Rotival, moreover, drew three sketches as possible scenarios for the urban development in the future, which "were later used by the local town planners when they were working on the first stage of their undertaking" (Senior, 1970, p. 73).

18 The very first UNESCO-facilitated earthquake engineers' visit took place in August 1963 upon the request of the Yugoslav government (more in: Ambraseys, 1968a; 1968b; Zátopek, 1968). The expert evaluation that the Skopje region is safe enough for rebuilding the torn city reaffirmed a similar assessment of the Yugoslav government from the immediate aftermath of the earthquake (publicized on 2 August 1963; more in Arsovski, 1989, p. 13). 
By April 1964, the ITPA finished its urban study and spatial design for Skopjeand the Skopjeregion in threeversions, thus concluding - what would be afterwards depicted as - the "first phase" of the outline plan design (Skopje: Prostoren koncept, 1965, p. 5). The "second phase" was marked, initially, by the UN decision to assign the American expert George Nez to cooperate with Kole Jordanovski, the then Director General of the Reconstruction and Development Program, as coordinators of the "international planning activities" (Senior, 1970, p. 82). These appointments came after the Consultative Board's meeting in February 1964 - a transnational body comprised of UN, UNESCO and Yugoslav experts - where it was restated that Skopje "would continue to develop as an administrative, economic, political and cultural center" of SR Macedonia, while the urban plan would be a subject of international competition. ${ }^{19}$ The winner of the international competition was the Greek studio Doxiadis Associates (DA), and the jury emphasized DA's founder Constantinos Doxiadis's "considerable experience in many parts of the world" as a rationale of the selection (Tolic, 2019, pp. 44-45). An architect, town planner and a leading theoretician of the Ekistics doctrine - an interdisciplinary take on human settlements with the goal of balancing natural and urban environments (more in: Doxiadis, 2005) - Doxiadis indeed had a "huge international role in the 1960s," coordinating UN-sponsored large-scale projects in many developing countries, including: drafting the plans of Islamabad, Baghdad and Dhaka (Lozanovska \& Martek, 2019, p. 509). Therefore, seven staff members of DA came to Skopje in late March 1964 and started co-working on the first outline plan alongside nine Yugoslav planners, with a deadline of a mere few months to finish the project. The final results of this cooperation were publicized in June 1964: relying upon the rapid preearthquake urbanization of Skopje, the plan assumed that the city would "continue indefinitely to grow apace" and, over the long term, projected accommodating 800,000 to 900,000 people (Senior, 1970, pp. 82-84).

The "second phase" was completed with the endorsement of Polish expert aid to the outline plan. In the wake of the Skopje earthquake, the Polish government started working on a separate, Polish state-sponsored plan for Skopje under the leadership of Adolf Ciborowski, the chief architect of Warsaw and planner of its post-war reconstruction, as part of the Polish Government Committee for Help to Skopje (Senior, 1970, p. 96). ${ }^{20}$ Ciborowski had already visited Skopje prior to the UN proposal

\footnotetext{
19 CSA, Skopje: Dnevni Jugoslovenski Operativno-Informativni Bilten o Obnovi i Izgradnju, Doneseni zaključoci na prvoj sednici konsultativnog odbora UN, 10 March 1964, 2-7.

20 The Poles and the Polish government responded to the disaster with a serious and structured operation, which entailed medical materials, clothing, and financial aid from July
} 
in a "socialist gift-exchange" ceremony (Lozanovska \& Martek, 2019, p. 509) and, after returning to Warsaw, he teamed up with a group of Polish urban planners, architects and engineers to work out an "alternative to the study which the UN had previously commissioned from the Greek-Yugoslav team in Skopje" (Veljanovski, 2019, p. 36; see also: Blaževski, 2017). ${ }^{21}$ The intense Polish interest in helping Skopje stemmed not only from the urban reconstruction experience with war-torn Warsaw (to "share the experiences of rebuilding Warsaw" as put in Skopje: Study of the Master Plan, 1964), but also from the "normalization" of Polish-Yugoslav relations after the political changes in the post-1956 Soviet bloc (for a historical overview see Wawryszuk, 2018). ${ }^{22}$ The initial plan published by the Warsaw Council Town Planning Office's (WCTP) Skopje Team (Pol. zespót skopijski) was thus drafted upon the initial sketches of ITPA, Zátopek and Ambraseys, and contained - albeit with "inadequate survey material" (Senior, 1970, p. 96) - several "courses of town-development from techno-economical aspect" by employing the so-called Warsaw optimization method: a method developed in, and applied to, post-war Warsaw's reconstruction that combined rational investments with computational analysis (Skopje: Study of the Master Plan,

to September 1963 (for an overview, see Jankowski, 1967; Mirchevska \& Jancheva, 2013; see also Your Aid to Skopje publications issued by the Committee for Reconstruction and Development of Skopje from 1963 to 1966), but also prefabricated housing and the project and realization of the Museum of Contemporary Art and the specialized chemistry high school "Marija Sklodovska-Kiri" in Skopje (more in: Kędziorek, 2014; Nettmann-Multanowska, et al., 2014).

21 The group consisted of, among others, Stanislaw Jankowski - team leader, WCTP Director; Bohdan Jastrzębski - Director of the Research and Design Office at Warsaw City Council; Maria Redziejowska - WCTP Head of the program team; Wojciech Suchorzewski - Deputy Director of the Research and Design Office for Roads and Transport at the Warsaw Council; Juliusz Wilski - WCTP Deputy Head; Stanisław Broniewski; Zbigniew Galperyn; Stanisław Furman; Czesław Kotela; Kazimierz Marczewski; Stefan Putowski; Zbigniew Sufin; and Bohdan Wyporek. All the Polish informants recall Jankowski's urgency when building the team - in the case of Galperyn, not even allowing him much time to consider the offer (personal interview with Zbigniew Galperyn, Warsaw, October 2019).

22 A brief look at the Polish media coverage of the 1963 Skopje earthquake reveals that the correspondents and specially sent journalists portrayed the disaster - almost exclusively - in catastrophic terms, oftentimes comparing it to the Warsaw tragedy during WWII and even a nuclear disaster (more in: Boczek, 1963; Eljasiak, 1963; Fethke, 1963; Ilicz, 1963; Konarz, 1963; Lazarewicz, 1963; Mozio, 1963; "Polscy projektanci," 1963; Robakowski, 1963; Simovič, 1963; Strzelecka, 1963). In November 1965, Józef Cyrankiewicz, the then Prime Minister of People's Republic of Poland, stated - on the occasion of the public presentation of the Skopje Urban Project in Skopje - that the Polish help to the earthquake-torn city also stemmed from the legacy of Polish-Yugoslav "brotherly" relations, manifested, as well, in Yugoslav brigades' help in the post-war Warsaw reconstruction. More in CSA, Skopje: Informativen Bilten, Partisko-vladina delegacija na NR Polska i Tito vo Skopje, 22 November 1965, 1-4. 
1964, pp. 44-51). ${ }^{23}$ Unlike the Greco-Yugoslav plan, the Polish plan took a rather "conservative view of Skopje's future growth" and urged limiting the Skopje population to 350,000 by 1981 by "deliberate diversion" of the city's potential employment growth to the "underdeveloped satellite towns" in the vicinity: Tetovo, Kumanovo and Titov Veles, and the far-end Skopje settlement of Gorče Petrov (Skopje: Prostoren koncept, 1965, pp. 14-15; Senior, 1970, p. 96). The rationale here hinted at the economic realism of eventual subregional development - a "proper distribution of productive power in the Republic" - while providing, in addition, a safeguard against another catastrophic earthquake in the Skopje region (Skopje: Study of the Master Plan, 1964, pp. 13-14). ${ }^{24}$

Finally, the "third phase" of the outline planning for post-earthquake Skopje commenced with the Consultative Board's consideration of the two plans in July 1964, before offering contracts, in August 1964, to Doxiadis Associates and the Polish Polservice - a state agency for the supply of professional land use and construction services - to cooperate with the ITPA in the upcoming work with the following division of labor: Polservice and ITPA were called to prepare the master plan, the social survey and the regional plan, while DA were allotted to prepare an area survey, a housing program, traffic and transportation projections, and infrastructure studies. Moreover, Ciborowski was appointed Project Manager - as "he was, of course, familiar with the problems" as supervisor of the Warsaw planning - while Wilbur Smith and Associates (from the US) were sub-contracted for the planning and traffic-engineering aspects of the road transport studies (Senior, 1970, pp. 103-105).

\section{The Survey}

The brief period between August 1964 (when the upcoming work on Skopje's reconstruction was approved), through October (when it was contracted), and December (when the social survey officially commenced), even though brief, is critical for the understanding of the rationale, the

\footnotetext{
23 The method was co-developed by one of my informants, Wojciech Suchorzewski, in the early 1960s (1961-1963); apart from Warsaw and Skopje, it was applied in 21 other cities in Poland (personal interview with Wojciech Suchorzewski, Warsaw, October 2019; see also: Broniewski \& Suchorzewski, 1979).

24 The plan, as such, also resonated with the so-called Warsaw City Complex idea from the post-war reconstruction of the Polish capital: a developmental "dispersed system" model of transforming the present settlements in the vicinity of Warsaw as "definite towns" while Warsaw, alongside its environs, would jointly develop within a uniform plan. The plan was co-authored by Jankowski, the team leader of WCTP's Skopje Team (more in Dziewulski \& Jankowski, 1957, p. 217).
} 
premises and the initial expectations behind this undertaking. One can assume that the immediate post-earthquake population influx to the city surprised the authorities, yet, in line with the "Open City" policy, the Skopje City Council sought to meet this novel tendency with a research survey - "statistical methods, demographic, comparative analyses, surveys" - of the "potential migration trends," anticipating that "a large portion of the evacuated" citizens would stay at the safe places, the "more propertied" ones would move to Skopje, while the "less propertied" would leave the city. ${ }^{25}$ Therefore, ITPA ordered several studies which were published among the aforementioned "preparatory-programmatic" works, yet, all the eight "economic reports" were negatively evaluated by a jury of two external experts in January 1964. The experts - Franjo Gašparević of Zagreb’s Town Planning Institute and Dušan Stefanović of the Federal Town Planning Institute - concluded that the reports contained "major weaknesses" and should undergo "a necessary revision [even if they are] considered only as informative materials" (Skopje, urbanistickka studija-2, 1965, pp. 15-21). Being aware of the international expertise coming to Skopje, the expert evaluators proposed appointing one "main programmer" who would be responsible for feeding information to the urban planners and cooperating with the lead planner and the "responsible political factors," while leaving the planning activities to the foreign experts as it "cannot be expected that the foreign experts could manage, in a short time span, to master the programmatic part of the work on the Skopje urban plan" (Skopje, urbanistička studija-2, 1965, p. 21).

The forthcoming set of events, however, took a slightly different turn. Already in late May 1964, the Skopje City Council publicized a set of directions for the forthcoming work on the Skopje urban plan, hinting at the "sociological and physiological" feedbacks which the Skopjans were supposed to contribute to the post-earthquake planning. ${ }^{26}$ These considerations took place just days before the Polish articulation of Skopje's "population problem" - that is, the expert evaluation that the rapid urban growth and migration to the city would cause employment issues in the industrial sector (Skopje: Study of the Master Plan, 1964, p. 24) - and, as such, influenced the final Consultative Board's decision to adopt the Polish urban population estimates for Skopje in the 20 -year-long planning perspective. ${ }^{27}$

\footnotetext{
25 CSA, Skopje: Dnevni Jugoslovenski Operativno-Informativni Bilten o Obnovi i Izgradnju, Sociološki aspekti novog generalnog urbanističkog plana Skopja, 29 May 1964, 1.

26 CSA, Skopje: Dnevni Jugoslovenski Operativno-Informativni Bilten o Obnovi i Izgradnju, Sociološki aspekti novog generalnog urbanističkog plana Skopja, 29 May 1964, 1-6.

27 This decision was further justified as a countermeasure to the eventual "hypertrophy" of the urban population, as well as a step toward a sustainable regional development and an establish-
} 
Illustratively enough, even though the DA were "hoping to be responsible" for the social survey (Tolic, 2019, pp. 58-59), prior to the Consultative Board's final granting decision, the local authorities in Skopje pointed out, in May 1964, that the "contemporary achievements of the Western European urban sociology cannot contribute much" to the planning of post-earthquake Skopje. ${ }^{28}$ Here, the Yugoslav "socialist democratism" was depicted as an "entirely different theoretical and ideological position" than those of the Western World, which were focused on the "narrow-class, technocratic or bureaucratic interests of various strata." 29

The Polish proposal for the social survey must have been received with relief by the local decision-makers in Skopje, as it came from another socialist country with more developed empirical sociological scholarship and a country with which they shared a legacy of academic exchange. ${ }^{30}$ The very first mention of "social studies/enquires, interviews and conclusions" can be found as a mere bullet point in WCTP's 1964 Skopje:

ment of "other immigration centers" across Macedonia. More in CSA, Skopje: Dnevni Jugoslovenski Operativno-Informativni Bilten o Obnovi i Izgradnju, O novom urbanističkom planu Skopja, 9 July 1964, 1-3.

28 Doxiadis himself approached Louis Miniclier - an early pioneer of the "community development" - asking him to serve as Head of the DA social planning team, while Miniclier was also looking for "bright young, imaginative behavioral scientists who are capable and willing to face up to the realities of operational situations." In his letter to Joel Halpern - an American ethnographer with fieldwork experience in central Serbia, who was considered for participation in the research team - Miniclier depicts the decision not to award DA the social survey contract for Skopje as a result of the tendency to rely on "personal experiences and intuition rather than invest in essential research and studies" (Tolic, 2019, pp. 58-59).

29 CSA, Skopje: Dnevni Jugoslovenski Operativno-Informativni Bilten o Obnovi i Izgradnju, Sociološki aspekti novog generalnog urbanističkog plana Skopja, 29 May 1964, 1.

30 Poland and Yugoslavia had an agreement for cultural cooperation as of 1948; the agreement envisioned academic exchange, translations and exhibitions. Polish Ministry of Foreign Affairs' Archive (PMFAA), Umowy Kulturalne [Konwencja o współpracy kulturalnej między Polską a Jugosławia 1946-1948], box 732 (21/51), 1-11. As of the 1950s, this sort of cooperation intensified by including various institutions - for instance, the Polish Academy of Sciences (PAN). More in: PMFAA, Umowy Kulturalne [polsko-jugosłowiańskie umowy o współpracy Kulturalnej w latach 1956-1961. Projekty umów, plany, notatki, korespondencja], box 733 (21/51), 1-8. On a different note, the Archive of PAN's Institute of Philosophy and Sociology (IP\&SA) reveals the Polish sociological community's interest in the scholarly developments in Yugoslavia: in 1958, Belgrade-based Komunist was the only journal from a European socialist state to which IP\&S PAN was subscribed, while in 1962, the Institute issued an official invitation for a two-month-long stay in Warsaw to Svetozar Livada - one of the leading Yugoslav rural sociologists. See IP\&SA, Biblioteka Instytutu Filozofii i Socjologii PAN [Korespondencja, rok 1955-1961], box 230/12 (54); Sprawy zagraniczne [Korespondencja rok 1962-1963], box 230/15 (58). The mutual scholarly interest resulted in a 1964 initiative to launch an annual Polish-Yugoslav philosophical and sociological conference, the rationale here being the legacy of cross-national cooperation for "many years" (Pol. od szeregu lat). See IP\&SA, Sprawy zagraniczne [Korespodencja rok 1962-1963], box 230/15 (58). 
Study of the Master Plan, with the number of four months for the study as the only additional information provided (1964, p. 12). Eventually, four of the initial Skopje Team members - Zygmunt Pióro (as a Head of the Social Survey Team), Andrzej Luszniewicz, Bożydar Rząd-Górnicki and Zbigniew Sufin - were assigned the roles of Polservice conveners of the social study alongside their counterparts from the ITPA - Mimoza Nestorova-Tomić, Časlav Teodosievski, Atanas Bančotovski, Vera Savin, Milka Andonova - and two translators, Pando Konstantinovski and Jan Plukowski. The selection of experts is also illustrative of the upcoming work on the survey. Pióro, an urban sociologist affiliated with WCTP, had certain knowledge of Macedonia as an assistant at Łódź University in the immediate post-war years to Józef Obrębski - a Polish social anthropologist who conducted "pioneering fieldwork in Orthodox villages of Macedonia" (Engelking, 2020) - and had extensive research experience in many Polish towns from the late 1950s and the early 1960s (more in: Sierniński, 1984). ${ }^{31}$ Luszniewicz, the other $\mathrm{PhD}$ holder on the team, was a statistician and a professor at the Warsaw School of Economics (after Skopje, he worked on the distance method, that is, the measurement of living standards and welfare based upon indices from natural units; more in Luszniewicz, 1974). The WCTP’s Rząd-Górnicki, as recalled by Sufin, had a formative role in building the Polish team for the social survey. Sufin, the only living member of the social survey team and a former journalist and a philosophy graduate, was affiliated with the weekly Po Prostu (more in Olszewski, 2013), the Center for Public Opinion Research in the late 1950s and the early 1960s - where he worked on several social surveys in Puławy, Świnoujście, Szczecinek, and Nakło (Sufin, 1964) - and the Institute of Philosophy and Sociology, Polish Academy of Sciences as of 1962, where he specialized in and taught labor sociology and the sociology of migration.

31 His research interest covered the sociology of the family, migrations, industrialization and urbanization - predominantly in an interdisciplinary scope of what he named a "social environment" (Pol. ekologia społeczna) inquiry (Pióro, 1962; an equivalent of the term, "ecological interpretations," would also be used in the Skopje social survey report as one of the methods of analysis related to the inquiry of the "spatial behavior of families and persons"; more in Report on social survey, 1965, p. 2). He drew inspiration from CIAM and the Athens Charter (Malisz \& Pióro, 1960, pp. 5-7), the French and the American urban sociology (Pióro, 1964), the Yugoslav pioneer of urban sociology, Cvetko Kostić, the first generation of Polish rural and urban sociologists - Bogusław Gałęski, Wacław Makarczyk, Zbigniew Wierzbicki (Ziółkowski, 1964), and the Warsaw optimization method theory (Karłowicz \& Pióro, 1964, pp. 24-38). Pióro obtained contacts with the UN as of 1960, when he also started publishing in English in the Quarterly Bulletin of the Society of Housing Managers, the Journal of the American Institute of Planners, and, finally, in Ekistics - in 1962 and 1965 (Pióro, 1962, 1965). 
The Macedonian partners were certainly not as sociologically versed as the Polish. Mimoza Nestorova-Tomić, the coordinator of the ITPA team for the social survey, had an architectural background and returned to Skopje from a short-termed fellowship in the US slightly before her appointment. Although her good command of the English and her attendance at an urban sociology course in the US made her a good candidate for the position, she vividly recalls the genuine help and readings which "Pióro and the Poles" provided her before the start of the fieldwork. ${ }^{32}$ The official launch of the survey was announced on 18 December 1964 with a press conference at Skopje City Council, where Pióro and Nestorova-Tomić presented the study - entitled "The Citizens of Skopje Plan Their City" (Mac. Graǵanite na Skopje go planiraat svojot grad) - and disclosed some details about it: more than 4,000 households from the entire urban area were planned to be approached, 180 students were to be employed, and the survey would unfold in two phases: an initial, pilot phase, consisting of a trial questionnaire distributed to 70 households, and the "real" survey, scheduled to be held from 3 to 20 January 1965. The conveners also stressed that the survey was envisioned in Skopje City Council's decision from 13 October 1964, which made it clear that the "urban planning must be directly linked with the social development of the city" while its results would be used to design urban planning policies up to $1981 .^{33}$ This link also featured in the conveners' descriptions of the survey's twofold goals - one informative and the other educational - which "would help the citizens to provide their most honest opinions on the future of their city." It should also be emphasized that the general tone of the event was positive and optimistic: the study was announced as an endeavor "which is highly anticipated, especially for the short-term [planning]." ${ }^{34}$ A similar tone prevailed in all the other references to the social survey from early 1965: for instance, in the midst of the fieldwork it was reannounced that it was expected to provide "very positive results." 35

\footnotetext{
32 Personal interview with Mimoza Nestorova-Tomić, Skopje, November 2019. The Polish team would end up providing a 30-hour intensive training to 80 people - 10 instructors and 70 "interviewers" (Mac. anketari), "students of law, technology, history, languages, philosophy, etc. at Skopje University" (Izveštaj od socijalniot pregled, 1965, pp. 12-13; Report on social survey, 1965, p. 6).

${ }_{33}$ However, certain hints to the social survey can be traced back to September 1964. On 17 September 1964, less than a month before the official announcement of the study, Macedonian daily press published an article which was critical towards the failure to include citizens' opinions in the urban planning prior to the earthquake, and anticipated such a "bottom-up" approach in the near future (more in Dogramadžiev, 1964).

${ }_{34}$ CSA, Skopje: Dnevni Jugoslovenski Operativno-Informativni Bilten o Obnovi i Izgradnju, Primena sociološke urbanizacije u izradi urbanističkog plana grada Skopje, 19 December 1964, 1-5.

35 CSA, Skopje: Informativen Bilten, Prvite rezultati od sociološkata anketa "Zbor imaat
} 
In practice, however, the research team encountered several challenges. The fieldwork deadlines were prolonged due to the difficulties in locating all the families from the random quota and area sampling as many of them had changed their temporary residences. The team thus managed to get back the questionnaires from 2,300 Skopjans by 1 February, announcing that they planned to contact "1,600-1,700 more citizens" in the upcoming days. In parallel to those questionnaires whose major purpose was to obtain information on housing, living conditions and family incomes, the team indicated that they would start interviewing 150 Skopjans as of February. These "extensive" interviews were expected to provide insights not only into the citizens' reflections over the city's future development, but also into such issues as their considerations when deciding on the place of residence, the level of satisfaction with the housing and the city services, etc. ${ }^{36}$ The hand-in-hand work on the questionnaires and the interviews was characteristic not only of the social survey, but it was a feature of the Skopje Urban Project in general: Senior compares the multilayered work to a "revolutionary situation" (1970), while Tolic depicts the "work on different levels and scales and without a specific order" using the metaphor of the "Neurathian boat" - rebuilding a ship on an open sea (Tolic, 2017, p. 55). The joint, interdisciplinary work on the social survey was also vividly recalled by the Polish experts, who stressed that the urban planners were oftentimes conducting the social survey fieldwork alongside the interviewers (see e.g. Sufin, 1967; Jankowski, 1967). Moreover, the role of the two formal and the other informal translators was also singled out as immensely important for the survey purposes - one of them, being a Macedonian child refugee to Poland from the Greek Civil War, was, in Sufin's words, "a representative of both cultures," thus providing additional legitimacy to the project in the eyes of the interviewees. ${ }^{37}$ In the end, only two families refused being interviewed for the "Citizens' Voice" (Mac. Zbor imaat graǵanite) survey, as it was now called using its popular and media title. The survey materials were passed on to the Republican Institute for Statistics, where they were subjected to cross-tabulation, while the team summed up the survey with a 100-page study, published in English and Macedonian by Polservice and the ITPA..$^{38}$

\footnotetext{
graǵanite", 1 February 1965, 5.

36 CSA, Skopje: Informativen Bilten, Prvite rezultati od sociološkata anketa "Zbor imaat graǵanite", 1 February 1965, 1-4.

37 The interviewees almost exclusively welcomed the interviewers in a good spirit, offering them a coffee and, in some cases, alcohol. Interestingly, Sufin notes similar responses to social surveying in Poland during the same time period (1981).

38 CSA, Skopje: Informativen Bilten, Što pokažaa javnite diskusii po osnovniot urbanistički plan na Skopje, 15 November 1965, 7-9.
} 
The study itself contains the rationale, the description of the work on the survey, the major research findings, as well as the appendices: the methods of choosing the observation units, the questionnaire, maps and tables. The survey's rationale here, apart from being the projected "fodder" for the urban planning activities, was reported to stem from the novel, postdisaster constellation, the "unreliability" of the 1961 population census, and the "necessity" of including the "variables [of] ethnic groups, communes and self-government" (Report on social survey, 1965, p. 1). The goals were thus presented as threefold: to obtain more detailed information on the citizens' individual and family plans, the motives behind immigration to Skopje, and the social activities of the Skopje population outside their residential districts. The study structured the major findings in five thematic scopes: "demographic and economic structure of households; work; housing; services; some social problems." The demographic section revealed significant discrepancies between the "demographically large households [of] mainly [the] three ethnic groups [of Albanians, Turks and Roma], predominantly manual workers" - who were mainly settled in the City Region B (the municipalities of Saat Kula and Dračevo) - and the "demographically medium and small size households [with] a relatively high professional activity index (mainly Macedonian and Serbian households, predominantly office workers)" - who lived in the City Region A (Idadija and Kisela Voda). ${ }^{39}$ Similar proportions reappeared in the "density dwelling" (Region A had the lowest occupancy rate), occupational activities (Region B had the lowest), and income per capita indices (Region A had the highest, Region B the lowest, with Region C, i.e. the municipalities of Kula and Ǵjorče Petrov, in between). The second chapter revealed that Skopje's population had a "comparatively high percentage" of unqualified workers who "[did] not propose to gain qualifications" - a visibly disproportional attitude compared to the "choice of profession for the children" index, which showcased that the locals had a "high interest in professions needing higher education" (Report on social survey, 1965, p. 50). The housing section revealed another "evident correlation": the higher the income per capita in a household, the lower the percentage living in pre-1945 houses (Report on social survey, 1965, p. 54). The assessments of the services-related questions revealed a strong centripetal tendency towards daily commuting to the city center - a "small town habit" in Senior's interpretation (Senior, 1970, pp. 265-270) - as there was "an unequal distribution of services thorough

39 According to the Skopje-based Economic Institute data, in 1963 Skopje had 182,190 inhabitants: 109,800 (60.4\%) Macedonians; 14,610 (8\%) Turks; 12,600 (7\%) Roma; 12,500 (6.9\%) Serbs; 11,150 (6\%) Albanians and 21,420 (11.7\%) of other ethnic origins (Izveštaj od socijalniot pregled, 1965, p. 18). 
the residential areas" (Report on social survey, 1965, p. 75). Finally, the section on the other social issues contained an interpretation that although almost half of the interviewees wanted to change their place of residence, only a small percentage of $14 \%$ informants wanted to change their current neighborhood (Report on social survey, 1965, pp. 84-85).

The final section, however, exposes one of the major upshots of the social survey: the underlying interethnic relations in the city, both before and after the 1963 earthquake. The publication thus reveals that the research team was facing issues of ethnic identity from the very beginning: the authors wrote it had been "practically impossible to interview the women of some ethnic groups (Turkish, Albanian)" (Report on social survey, 1965, p. 4), while the numbers of Roma informants was also reported to be lower than anticipated on several occasions. The study also contained clear indications that the number of members of a particular household correlated with ethnicity (with Serb families being the smallest, Turkish, Albanian and Roma the largest, with Macedonian families in between) and, moreover, that the Albanian and Turkish families tended not to change residence even if living in substandard conditions. Alongside these findings, these figures hinted that the tendency towards ethnic neighborhoods in Skopje did not cease to exist in the post-1963 period. This complex set of questions thus shifted from being a non-issue prior the survey - for instance, there was no reference to interethnic issues in the initial Polish proposal for Skopje's outline plan - to being one of the key research findings, even though the factor of "nationality" was reported to be of an indirect rather than a decisive nature for the future town planning of Skopje (Report on social survey, 1965, p. 3). However, in the aftermath of the publication of the study, several of the Polish team members would evaluate the ethnic-related issues in Skopje in a slightly different key: Jankowski, for example, in his 1967 paper on the Polish involvement in Skopje's reconstruction, noted a minority-related issue - Skopje's Turks, Albanians, and Roma with low labor qualifications prioritize the location rather than the technical standard of the house - as the first of the three main takeaways from the social survey. ${ }^{40}$ Seniot put a similar accent on the social survey results, as he understood both the social survey and the housing sections of the Skopje Urban Project as attempts to "reconcile [the] unexceptionable aim of improving the substandard living conditions of the ethnic minorities with the equally estimable purpose of cherishing their distinctive cultures" (Senior, 1970, 265).

\footnotetext{
40 The other two being also related to ethnic identities: family and neighborly ties are highly valued and are often a determining factor in many other domains; the predominantly rural-urban migrations to the already settled families in Skopje are a factor behind the higher demand for larger houses (Jankowski, 1967, p. 8).
} 
The immediate Macedonian reactions to the survey did not give such priority to the issues related to ethnic identity. In 1965, the ITPA prepared an overview report of the Skopje Urban Project that contained a one-page summary of the conclusions of the social survey without referring to the various issues concerning the ethnic minority groups. The authors of the report did however provide several other directions to be implemented in the planning activities: integrating both sides of the city - divided physically, by the Vardar River, and symbolically, by the ethnic neighborhoods - by establishing "public, cultural, and other objects with integrative functions" and strengthening the social capital in the city (Skopje, rezime, 1965, p. 12). Even though the idea of reimagining the city center as a space of intercultural exchange would be further articulated in the plan for the city center, it is important to note that it actually stemmed from the social survey findings. ${ }^{41}$ In other words, the Polish experts saw the centripetal tendency of daily communication as a potential factor to be exploited in facilitating post-1963 interethnic coexistence in the city. This general perception manifested both as recognition of the indispensable value to the city of Skopje of the centrally located Ottoman Bazaar (NestorovaTomić recalls that it was Ciborowski who saved the Bazaar from demolition in the middle of the night; more in Lozanovska, 2016, pp. 129-130), and as inspiration for urban and architectural projects for the city center: one of these, as recalled by Sufin, would include a representational objects of each cultural group in the Skopje city center (Sufin, n.d.). ${ }^{42}$ Turning back to the period after the publication of the social survey results, it can be concluded that the survey was also communicated as a means of legitimizing the urban reconstruction in the local context. Here, the Skopje Master Plan would be officially publicized in October 1965 with an exhibition entitled Skopje in the Future (Mac. Skopje vo idninata), which was attended by a Polish delegation led by the Mayor of Warsaw and the Polish Ambassador to Yugoslavia, and meetings and discussions with the

\footnotetext{
${ }_{41}$ Tange had a vision of establishing a "nucleus" in the city center of Skopje as a "distinct zone with numerous facilities and public amenities located along the river banks, dominated by two central squares on each side of the river"; it was to serve as a meeting point for the different cultures in Skopje. This project, however, was not realized and the city square "never became the unifying core as intended, but more of an urban void" (Poposki \& Todorova, 2016, p. 99).

${ }_{42}$ As put in the social survey section of the summary of the Skopje Master Plan, one of the recommendations stemming from the survey was to integrate the Bazaar in the modern city center and to keep it "alive" by stimulating the economic relations occurring there. As a result, the Bazaar would not become a "museum", a relic of times long past (Osnoven urbanistički plan, 1965, p. 59).
} 
citizens of all the municipalities of Skopje. ${ }^{43}$ The exhibition was a distinct success, attracting more than 30,000 citizens in less than a month.

\section{The Aftermath}

The "Open City" politics facilitated the population influx to the city of Skopje after the 1963 earthquake. In 1973, for instance, the city's population was ten times that before the war, while in comparison to 1963 , it had grown by 117,583 inhabitants (Janković, 1982). In 1982, the estimated population was 519,798 (Skopje, 1963-1983, 1983, p. 9), outpacing the urban planning forecasts from the mid-1960s by almost 20\% (Ladinski, 2017 , p. 442). Regardless of the authorities' intentions to foster the city's development and, moreover, to "abolish the socio-ethnic difference, but, simultaneously, to preserve the specific cultural characteristics" (Osnoven urbanistički plan, 1965, p. 59), the challenges brought about by this influx proved the Polish experts right: the unemployment rates grew uncontrollably - in just a year, from 1972 to 1973, by almost $10 \%$ - while the urban infrastructure turned out to be insufficient to serve the new social reality. This, in turn, translated into various issues over shortages of educational facilities, informal and illegal housing, and even registration of the newcomers. Hence, as of the early 1970s and, especially, as of 19721973 and the reinstallation of the more conservative elite in power in SR Macedonia, it became a commonplace to criticize the politics of the "Open City" in the Macedonian public.

The critical discourse evolved over time: while in the 1970s the "Open City" politics was generally perceived by the local elites as "too liberal" (Doberšek, 1973), in the early 1980s it was depicted as a "paradox" and the main source of the political tensions in the state (Paškovski, 1983). This shift, however, had much to do with the economic crisis in Yugoslavia which in SR Macedonia it unfolded in a particularly harsh manner: in the mid-1980s, for instance, the average salary in the republic was $30.6 \%$ lower than the Yugoslav average (Jović, 2009), while 140 strikes were registered only over the course of the very same year (Jančeva \& Litovski, 2017, p. 179; see also: Hudson, 2003; Woodward, 1995). The crisis also brought the state funding of the Operative Program - the renamed Fund for Renewal and Reconstruction of Skopje as of 1974 - to a definite end, thus halting the post-earthquake reconstruction of the city while the funding for the less-

\footnotetext{
43 CSA, Skopje: Informativen Bilten, Otvorena izložbata "Skopje vo idninata", 25 October 1965, 1-3. According to Jasna Stefanovska and Janez Koželj, it was "the most comprehensive town planning exhibition ever staged in Yugoslavia” (Stefanovska \& Koželj, 2012, p. 93).
} 
developed Yugoslav republics and areas was not only halved by the federal authorities, but was also delivered with delays of several years.

Two experts on the interethnic relations during the Macedonian late socialism, Irena Stawowy-Kawka and Marijana Stamova, agree on the argument that the economic crisis was correlated with the deterioration of the interethnic - predominantly Macedonian-Albanian - relations in SR Macedonia in the 1980s (more in Stamova, 2017; Stawowy-Kawka, 2014). Tito's death and the protests in Kosovo, both in 1981, appeared to be particular triggers for numerous political forums in Macedonia, which, ultimately, led to unanimous portrayal of this tendency as Albanian nationalism, irredentism, and separatism. ${ }^{44}$ In practice, this meant radical changes in the politics towards the ethnic minority groups in the state: while the major push in the 1970s was to control the population influx to Skopje, in the 1980s the main rationale was to combat the pressing "Albanization" and "Islamization" of Macedonia. The results of the 1981 population census in Macedonia exacerbated the authorities' fears: the total number of ethnic Macedonians in the state had dropped by two percent, while the numbers of the Albanian and Roma populations had almost doubled over the course of a decade..$^{45}$ Therefore, the mid- and late 1980s in SR Macedonia were marked by two prevailing political strategies for governing interethnic relations. On the one hand, the demographic tendencies were frequently depicted as a result of the "civilizational gap" between the ethnic Macedonians and, mainly, the ethnic Albanians in Macedonia. ${ }^{46}$ This ideology led to a cut of social support for families with three or more children in 1988 - a policy which although targeted ethnic Macedonian families as well, was communicated as an instrument for fighting the "backwards and insufficiently developed human relations between the genders" (Paškovski,

\footnotetext{
${ }_{44}$ The 1981 protests in Kosovo, similarly to the ones in 1968, were held in several Macedonian towns with significant Albanian population. The protesters' demands in 1981 varied from a republican status of Kosovo to its unification with the People's Socialist Republic of Albania (more in: Hetemi, 2020).

45 In absolute numbers, the 1981 census counted 1,912,257 citizens in SR Macedonia, out of which 1,281,195 were ethnic Macedonians; 377,726 - Albanians; 86,691 - Turks; 44,613 Serbs; 43,223 - Roma; 39,555 - Muslims; 14,240 - Yugoslavs; 6,392 - Vlachs; 3,940 - Montenegrins; 3,349 - Croats; 1,984 - Bulgarians; 709 - Greeks; 667 - Slovenians. In percentages, the ethnic Macedonian population was 67\%, the Albanian - 19.8\%, and the Turkish $-4.5 \%$ (more in: Janković, 1982).

46 According to the official data, however, 21,245 people migrated from Kosovo to Macedonia from 1971 to 1981, while approximately 5,600 moved from Macedonia to Kosovo (Milić \& Krstić, 1988). For a critical take on the population politics in 1980s Macedonia, see Brunnbauer, 2004. Macedonian historians dealing with this period interpret the population influx to post-1963 Skopje, by and large, as a "demographic flood" which contributed to the interethnic tensions in the city (see e.g. Ačkoska, 2003; see also: Radičeski, 2013; Veljanovski, 2002).
} 
1988) - and the demolition of walls surrounding houses in Tetovo, in 1986 (Marić, 1986), and in Kumanovo, in 1988 (Milić, 1988), two towns with significant Albanian communities. On the other hand, the boiling interethnic tensions were discursively presented as the realization of an Albanian political agenda in Macedonia and Yugoslavia, one which had the ultimate goal of creating Greater Albania. ${ }^{47}$ Property purchases in Western Macedonia, for example, were interpreted in this key - according to the media, 578 Macedonians sold their houses to Albanians from 1981 to 1985 (Marić, 1986) - as was the renaming of children in Tetovo - an affair which led to several dismissals of party officials and, in 1988, to a law on personal names which forbade names suggesting Albanian nationalism (for a context, see Neofotistos, 2004) - and the "Albanization" of Macedonian Muslims (more in: Limanovski et al., 1984; Ramet, 1984).

The 1964-1965 social survey, in this context, was followed up in two distinct ways up to the fall of the socialist regimes in Yugoslavia and Macedonia. Undoubtedly, it would be the conveners of the study who benefited the most in the immediate years after this cross-national endeavor in line with their aspirations for establishing "Skopje's example of collaboration between sociologists and urbanists" as a "corner stone" for further transnational research (Osnoven urbanistički plan, 1965, p. 15). These aspirations were informed by the general atmosphere during the post-earthquake reconstruction of Skopje: the city was certainly perceived as a "platform for exchange between architects and planners across the Cold War divide" (Martek \& Lozanovska, 2018), while the Cold War constellation per se, according to Łukasz Stanek, brought "new geographies of collaboration" and extended the transnational ties to Middle East and Western Africa (Stanek, 2020, pp. 2-3). In the Polish case, the "Skopje experience" appeared to be formative for almost all the experts involved. Ciborowski continued to work as a coordinator of UN projects on the Adriatic coast (alongside two other members of the Skopje Team, Furman and Wyporek; more in Gzell, 2011, p. 24). Furman and Wyporek, alongside the ITPA's Kole Jordanovski, were called upon by the UN to draft a reconstruction plan for Chimbote after a series of disastrous earthquakes in Peru in 1970. Wyporek continued his career as a UN expert in Libya, Kenya and at UN-Habitat, where Suchorzewski had already been appointed an expert, while Furman moved to Lagos, Nigeria, where he worked on town planning. In his autobiography, published in 2009, Wyporek writes that "no one at the WCTP could predict that this earthquake far away would

\footnotetext{
47 See Stamova and Stawowy-Kawka (Stamova, 2017; Stawowy-Kawka, 2014) for the agency of the Albanian political diaspora and the People's Socialist Republic of Albania in the interethnic tensions in Macedonia. See also: Neofotistos, 2004; Poulton, 1995.
} 
have such an impact on the Institute's work and would change the life paths of a large group of Warsaw urbanists" (Wyporek, 2009, p. 25). Pióro's case is of particular significance here, as he was employed as a UN expert in Tanzania from 1965 to 1969, an experience which he further materialized as a novel research agenda on the geography of developing countries back in Poland: from 1977 to 1981, he served as Head of the Institute of Africanology at Warsaw University teaching and publishing several papers on this topic (for an overview, see Pióro, 1977). Moreover, in the Yugoslav case, the work on the Skopje Urban Project fostered the process of what Bojana Videkanić refers to as "nonaligned modernism" - the intensification of the transnational political, diplomatic and cultural relationships beyond the Western modernist ethos, which enabled a larger international presence of the Yugoslav experts (2020, pp. 8-10; see also: Kulić, 2014; Spaskovska, 2018). In Macedonia, more precisely, when the reconstruction of Skopje was slowing down in the late 1970s, "Beton and other Macedonian construction companies started to participate in projects abroad, generally as subcontractors of larger, Yugoslav import/export companies" (Mattioli, 2020, p. 26).

It is hard to find any references to the social study in the 1970s and 1980s Macedonia, although one would expect that the mid-1960s findings could be used by the authorities in attacking the post-1963 demographic, population and migration politics. In addition, the social study was not mentioned in either the scholarly or popular literature of the 1970s on the post-earthquake reconstruction, or was it referred to during the 1980s in the emerging critical discourse on the post-earthquake reconstruction of Skopje. An emblematic case here is the first ever urban-sociology-tagged paper published by the Institute for Sociological, Political and Juridical Research (ISPJ). Even though arguing in favor of a lessening of the "migration pressure" on Skopje and critical of the post-earthquake estimations for the population growth up to 1981, the paper did not refer at all to the 1964-1965 social survey (Tufli, 1978, p. 205). A similar tendency can be observed in a set of state-sponsored materials related to the 1963 Skopje earthquake and the post-earthquake reconstruction published in the 1980s. With the twentieth anniversary of the earthquake as a specialoccasion, several state institutions helped the publishing of several monographs dealing with the urban history of the Macedonian capital. These publishing activities occurred in a different context than the immediate post-earthquake decade - as discussed above - and they can be read in the key of - what I argue elsewhere to be - shifting the paradigmatic memory regime of the 1963 Skopje earthquake in the early 1980s (Trajanovski, 2021b). For instance, in the monographs on Skopje published in the 1980s the urban population 
figures were treated as a byproduct of the post-earthquake reconstruction in toto (see Kočiški, 1983; Popovski, 1983; see also: Bubevski, 1985). Another interesting case, in this regard, is the Skopje City Council's commissioned research project on Skopje's "constructing legacies" which took place in the 1980s and resulted in three monographs. Even while praising the post-earthquake reconstruction, the authors were critical of the migration politics and, especially, the "modern and functionalist" urban planning of Skopje up to 1970 (Arsovski, 1989, pp. 26-27). These critical discourses became prevalent in the period when the local authorities revised the city's Master Plan (1985), for the first time after 1965. Contrary to the "Open City" politics, the new plan projected limitations in the city population up to year 2000 (Padori, 1985).

The anomaly of the new urban politics, as initiated by the new Master Plan, was that it entirely relied on the state optics over the interethnic tensions of the day and thus it overlooked the pressing developments in the city; although an attempt by ISPJ was made to mirror, in a way, the 1964-1965 social survey, an episode which will be further discussed below. For instance, as of the mid-1980s, the media started reporting on the process of "ethnic filtration" in Skopje: the Albanians who were granted apartments in the new residential complex Aerodrom in Skopje-East were immediately selling them below the market prices or exchanging them for smaller units in Skopje-North. Even though several Albanian informants stressed that the major rationale for these resettlements was the lack of schools with teaching programs in Albanian in Aerodrom, the city authorities depicted this tendency as yet another manifestation of "Albanian nationalism" (Paškovski \& Stefanović, 1987; Saveski, 1987). As a response, the authorities passed a resolution on a temporary halt of the housing market, while the media was speculating over "expropriation" of the Skopje Bazaar claiming that it lies on an archaeological site and presents a public interest, but also emphasizing that the private stores there were being bought en masse by Albanians (see e.g. Neorčić, 1988). In this very context appeared the first ever post-1960s reference to the 1964-1965 social study in the Macedonian public. The critical agent here was Ilija Aceski, a sociologist affiliated with ISPJ in the 1980s and the Faculty of Philosophy, as of the 1990s. Drawing upon his participation in two ISPJ's research projects in the 1980s - the "Skoplan80" and the 1985 survey of the housing politics in Skopje - he argued that the 1985 Master Plan was "below the level" of the 1965 one. It is crucial to mention that the results of the two studies were communicated to the Macedonian public only when he published his observations in the 
mid-1990s. ${ }^{48}$ As an argument for his claim, Aceski juxtaposed the new projects' findings with the those of the 1964-1965 social survey: the city was overpopulated - he framed this peculiar outcome as "hyper-urbanization" (Aceski \& Matilov, 1997, p. 32) - and the citizens' preferences for "ethnic settlements" mapped in the mid-1960s - with places of worship and the established neighborly relations as anchors (Osnoven urbanistički plan, 1965, pp. 60-61) - were still relevant in the late 1980s and the early 1990s. Moreover, he criticized the local authorities' failure to address the ethnic division in the city - along the Vardar River, according to the 1964-1965 study - in the new Master Plan: it was as if it had "suddenly disappeared" (Aceski, 1996b, p. 52). This, in turn, led him to conclude that the city had been in a "permanent state of an earthquake" since 1963 (1996b, p. 52), and that the main reason behind the ongoing substandard conditions was the failure to implement the agenda of the 1965 Skopje Master Plan (1996a, pp. 99-101).

Aceski's interpretations, however, were only published in the mid1990s, a period marked by the Yugoslav wars and, as of September 1991, the Republic of Macedonia's attempts to deescalate the mounting interethnic tensions. The new social and political context thus shifted, anew, the dominant public discourses over the interethnic relations in the city: now, for instance, it would be the ethnic Macedonians who changed their perspectives and preferred to live in ethnically homogeneous settlements. ${ }^{49}$ This tendency was building bot only upon the late 1980s fear of "Albanian nationalism and separatism" - according to a 1988 ISPJ survey, $36.7 \%$ of ethnic Macedonians viewed the interethnic relations in the Republic as "bad" or "mainly bad," while $90 \%$ thought that state measures against "Albanian nationalism and separatism" were milder than necessary (Kočan, 1988) - but also via the early 1990s episodes of nationalist political campaigning. However, even though the state managed to avoid bloodshed in the 1990s, the Macedonian security

48 In addition, from 6 to 21 July 1993, Aceski published a feuilleton in Večer in 17 installments titled "Skopjans for Skopje" (Mac. Skopjani za Skopje) which presented the results of a research on the city of Skopje and "its spatial and physical buildout" - conducted by a group of students affiliated with the Institute of Sociology and Philosophy at the Skopje University in early 1993 and coordinated by Aceski. In the feuilleton published on the occasion of the thirtieth anniversary of the 1963 Skopje earthquake, Aceski also interpreted the research findings in light of the 1965 Master Plan and criticized the post-earthquake urban reconstruction of Skopje as conducted in the most "unpredictable and unacceptable" ways possible (more in Aceski, 1993). 49 In a 1997 study conducted by researchers from the Faculty of Philosophy at Skopje University, ethnic Macedonians had the highest percentage of affirmative answers to the question concerning "ethnically homogeneous settlements," and the lowest percentage of affirmative answers to the question concerning "ethnically mixed settlements" (more in Taševa et al., 1998, pp. 143-151). 
forces clashed with Albanian insurgents in 2001, a violent conflict which resulted in more than 200 casualties and over 100,000 exiled and internally displaced people. This traumatic event left open space for an even more radical rebuke of the post-earthquake migration and demographic politics, which eventually led to an ethnonationalist reimagination of Skopje, its central area and symbolic spaces. In brief, following the Greek veto of the Republic of Macedonia's accession to NATO in 2006, the right-wing government launched a project - called "Skopje 2014" - of erecting more than 130 monuments and memorial objects in the city in the late 2000s (for an overview, see Trajanovski, 2021a). The project, even though targeting a wide range of historical figures, events and periods, was especially brutal towards the socialist architectural and urban planning legacies in the city. Janev, for instance, notes a logic of "chronic neglect and silent destruction" of this heritage in the 2010s (Janev, 2017, p. 160), while Cvitković and Kline observe a particular strategy of "annihilation of the socialist period" in Skopje (Cvitković \& Kline, 2017, p. 34). ${ }^{50}$

The "Skopje 2014" project also reinvigorated the domestic and international interests in the post-earthquake reconstruction of the city: several curatorial projects and numerous articles emphasized the 1960s mode of aestheticism and solidarity as contrapuntal to the nontransparent implementation of "Skopje 2014" and the interethnic divisions it formalized. ${ }^{51}$ Such was the critical context of the final rediscovery of the

\footnotetext{
50 This strategy was manifested in a total makeover of façades (e.g. the NAMA Department Store, the building housing the government of today's North Macedonia, the project for refurbishing the City Trade Center), negligence and bad management (the Museum of Contemporary Art in Skopje and the Goce Delčev Student Dormitory), and obscure concealment with other objects (the Macedonian Opera and Ballet House and the Head Office of the Postal Service of North Macedonia).

51 One can mention the exhibition Skopje - Macedonian Architecture in Context, organized by the Ringturm Galerie in Vienna in 2017, and New York's MoMA's Toward a Concrete Utopia: Architecture in Yugoslavia, 1948-1980 in 2019. The museal space became a stronghold against the oblivion of the post-earthquake reconstruction in Macedonia as early as in the late 2000s, with the Museum of the City of Skopje and the Museum of Contemporary Art being the key institutions showcasing exhibitions of the post-earthquake solidarity (2009-2011), the so-called Solidarity Meetings (2010-2011), the cinematic depictions of the earthquake (2014), and the trans-Yugoslav solidarity to Skopje (2018; for an overview, see Trajanovski, 2021a). The history of the Museum of the Contemporary Arts would trigger the rediscovery of the Polish legacies of technical and expert aid as well as artwork donations to Skopje which, again, initially appeared as a curatorial project. In 2014, the Polish Association of Authors (ZAIKS) prepared an exhibition on the three Polish architects who designed the Skopje Museum of Contemporary Art - entitled The Warsaw Tigers: The Power of a Team - which was followed by a bilingual catalogue in English and Macedonian (Nettmann-Multanowska, 2014). In 2019, the Kraków-based International Cultural Center hosted an exhibition Skopje: City, Architecture, and Art of Solidarity, which focused on the Polish artwork in Skopje and the memorabilia of the Polish experts involved in the post-earthquake reconstruction of the city.
} 
1964-1965 social survey, this time in the scholarly discourse on Skopje. However, the invocation of the social survey in the 1990s can be viewed as an instrument for pointing out the shortcomings of the mid-1980s urban planning and applauding some solutions introduced in the mid-1960s, whereas the references to the survey in the late 2000s and the 2010s were utilized in an entirely opposite context: to argue that the post-earthquake urban policies generated, in fact, fragmentation along ethnic lines in the city. In his 2007 study, Robert Home argues that the "Skopje master planners showed themselves to be self-confident and interventionist social engineers" who held an ideology which favored "the rehousing of "slum inhabitants" and integrating "a homogeneous society adapted to modern urban life." Drawing upon the social survey, Home concludes that this was a politics without a precedence in Macedonia: the Ottoman administration in the city maintained segregated communities - a legacy that informed much of the social survey's answers. Moreover, he depicts the interpretation of the study by the urbanists as over-simplistic: they narrowed down the groupist behaviors of the Turks, who "were seen as attaching greater importance to the privacy of family life," and the Roma, who "lived gregarious, outdoor lives" (Home, 2007, pp. 2-22). Milan Mijalkovik and Katharina Urbanek's study from 2011 locates the "seed of fragmentation" in the modular urban planning instead: even though aware of the dissent of members of ethnic minorities over resettling (as showcased by the social survey), the authorities treated these refusals as "dysfunctional" - against the community and the sociopolitical order (Mijalkovik \& Urbanek, 2011, pp. 18-21). Finally, in her 2015 study, Ophelie Véron argues against the claim that the post-earthquake urban planning in Skopje was "neutral" using the findings from the 1964-1965 social survey. Similarly to Mijalkovik and Urbanek, she observes that the authorities failed to acknowledge the citizens' expectations as expressed in the survey, while the survey's emphasis on the risk of division was not followed "by any appropriate measures or practical efforts to counter it" (Véron, 2015, pp. 163-166).

\section{Conclusions}

This paper has dealt with the Polish expert aid in the operationalization and implementation of the Skopje social survey in the wake of the 1963 Skopje earthquake and its aftermath. As argued here, the survey was an exceptional endeavor, the first of its kind in the history of Skopje, and illustrative of some of the recurring theoretical, methodological and logistical issues 
of Skopje's post-earthquake reconstruction. The results of the study, however, were the subject to divergent interpretations after the end of the project. In the immediate aftermath, the Polish and the Macedonian experts had opposing stances. The Poles focused on the interethnic relations in the city, the several urban planning issues which might appear due to the different religious and ethnic affiliations, and they aimed at bridging the interethnic cleavages. On the other hand, their Macedonian counterparts were not as explicitly engaged in interpreting the interethnic issues arising from the social survey in the context of the urban planning activities. Later on, the study was not discussed in the Macedonian public in the 1970s and 1980s, while in the 1990s, it was reintroduced as a dataset which contained substantive arguments against the revised Skopje Master Plan from 1985. Finally, the study was evoked in the late 2000 s and the 2010 s by a group of foreign scholars, following the announcement of the "Skopje 2014" project. Their usage of the study was different than the one in the 1990s: the invocation of the social survey in the 1990s can be viewed as an instrument for pointing out the shortcomings of the mid-1980s urban planning and applauding some solutions introduced in the mid-1960s, whereas the references to the survey in the late 2000s and the 2010s were utilized in an entirely opposite context. Namely, to argue that the post-earthquake urban policies in fact generated the fragmentation along ethnic lines in the city.

\section{References}

26 juli 1963 - Žrtvi na skopskiot zemjotres. (1963). Centar za informacii na Gradskoto sobranie na grad Skopje.

Aceski, I. (1996a). Skopje - sociološka studija. Ekopress.

Aceski, I. (1996b). Skopje: Vizija i realnost. Filozofski fakultet - Skopje.

Aceski, I., \& Matilov, N. (1997). Razvojot na urbanite centri vo Republika Makedonija. Institut za sociološki i političko-pravni istražuvanja.

Ačkoska, V. (2003). Bratstvoto i edinstvoto 1944-1974: Pomeǵu harmonija $i$ disharmonija. Institut za nacionalna istorija.

Adamson, K., \& Jović, D. (2004). The Macedonian-Albanian political frontier: The rearticulation of post-Yugoslav political identities. Nations and Nationalism, 10(3), 298-301. https://doi.org/10.1111/j.1354-5078.2004.00168.x

Ambraseys, N. N. (1968a). An engineering seismology study of the Skopje earthquake of 26 July 1963. In Unesco earthquake study missions: The Skopje earthquake 1963 (Vol. 66; pp. 35-88). UNESCO.

Ambraseys, N. N. (1968b). General characteristics of the Skopje earthquake - a summary. In Proceedings of the international seminar on earthquake engineering - Skopje 1964. Held under the auspices of the Federal Government of Yugoslavia and of Unesco, Skopje, 29 September to 2 October (pp. 81-85). UNESCO. 
Anakioski, D. (1967). Kretanje zaposlenosti i promene u socijalnoj strukturi stanovništva SR Makedonije. Stanovništvo, 5(4), 293-304.

Archer, R. (2018). The moral economy of home construction in late socialist Yugoslavia. History and Anthropology, 29(2), 141-162. https://doi.org/10.1080/02757206.2017.1340279

Arsovski, T. (1989). Skopje: Urbanizam i arhitektura 1945-1985 (Kniga III). Sobranie na grad Skopje.

Bielińska-Kowalewska, K. (2012). Kako je poljski revizionizam mimoišao tzv. praxisfilozofiju: Recepcija jugoslovenske filozofije u Poljskoj tokom 60-ih i početkom 70-ih u kontekstu sudbine poljskog revizionizma i njegove karakteristike. In D. Olujić \& K. Stojaković (Eds.), Praxis: Društvena kritika i humanistički socijalizam (pp. 269-293). Roza Luxemburg Stiftung.

Bishop, L., \& Kuula-Luumi, A. (2017). Revisiting qualitative data reuse: A decade on. SAGE Open, 7(1), 1-15. https://doi.org/10.1177/2158244016685136

Blaževski, B. (2017, September 24). Postzemjotresna obnova na Skopje: Voved vo eden podzaboraven diskurs. Built.mk.

Bojić, N. (2019). Social and physical planning: Two approaches to territorial production in socialist Yugoslavia between 1955 and 1963. Architectural Histories, 7(1), 1-17. https://doi.org/10.5334/ah.309

Borota Popovska, M., \& al. (Eds).(2015). 50 godini Institut za sociološki i političko-pravni istražuvanja 1965-2015. Institut za sociološki i političko-pravni istražuvanja.

Broniewski, S., \& Suchorzewski, W. (1979). Metoda optymalizacji warszawskiej. In R. Kulikowski \& J. W. Owsiński (Eds.), Zastosowanie analizy systemowej $w$ modelowaniu rozwoju regionalnego (pp. 91-102). Państwowe Wydawnictwo Naukowe; Instytut Badań Systemowych.

Brunnbauer, U. (2004). Fertility, families and ethnic conflict: Macedonians and albanians in the Republic of Macedonia, 1944-2002. Nationalities Papers, 32(3), 565-598. https://doi.org/10.1080/0090599042000246406

Brunnbauer, U., Kraft, C., \& Schulze Wessel, M. (2011). Introduction: Sociology and ethnography in East-Central and South-East Europe under state socialism. In U. Brunnbauer, C. Kraft, \& M. Schulze Wessel (Eds.), Sociology and ethnography in East-Central and South-East Europe: Scientific self-description in state socialist countries (pp. 1-28). Oldenbourg Verlag.

Bubevski, D. (1985). Nekoi aspekti na nacionalniot sostav na naselenieto vo SR Makedonija vo periodot 1948-1981 godina. MANU.

Cvitković, S., \& Kline, M. (2017). Skopje: Rebranding the capital city through architecture and monuments to remake the nation brand. Sociologija $i$ Prostor, 55(1), 33-53.

Davis, I. (1975). Skopje rebuilt: Reconstruction following the 1963 earthquake. Architectural Design, 45(1), 660-663.

Deipenbrock, E., \& al. (2010). Research Projekt: Skopje - A Modern City? Hafen City Universität. https://docshare.tips/research-project-skopje-a-moderncity_575027a4b6d87f211f8b46f4.html

Doxiadis, C. A. (2005). Towards an ekistic theory. Ekistics, 72(430-435), 39-66. https:// doi.org/10.5281/ekistics.v72i430-435.150 
Duller, M. (2018). Yugoslav sociology: Political autonomy under a single-party regime. In A. Hîncu \& V. Karady (Eds.), Social sciences in the "Other Europe" since 1945 (pp. 159-184). Central European University Press.

Dziewulski, S., \& Jankowski, S. (1957). The reconstruction of Warsaw. The Town Planning Review, 28(3), 209-221.https://doi.org/10.3828/tpr.28.3.p0345h13wp63416x

Engelking, A. (2020). Introduction. In J. Obrębski, The Giaours of Macedonia (pp. 7-10). Oficyna Naukowa.

Filip, J., \& Crvenkovski, K. (1993). Podvodni grebeni na politikata. Makedonsko radio.

Fisher, J. C. (1964). The reconstruction of Skopje. Journal of the American Institute of Planners, 30(1), 46-48. https://doi.org/10.1080/01944366408978088

Flere, S. (1994). The development of sociology as a contested science in Post-World War II Yugoslavia. In M. F. Keen \& J. Mucha (Eds.), Eastern Europe in transformation: The impact on sociology (pp. 113-124). Greenwood Press.

Galjer, J. (2019). Radical or not at all? Architectural criticism as a vehicle of CIAM and Team 10 networking in socialist Yugoslavia. In N. Correia, M. H. Maia, \& R. Figueiredo (Eds.), Revisiting post-CIAM generation: Debates, proposals and intellectual framework (149-166). CEAA/ESAP-CESAP.

Georgievski, P., \& Gurovska, M. (2003). Macedonian sociology in the 1990s: Between the old conceptions and new challenges. In M. F. Keen \& J. L. Mucha (Eds.), Sociology in Central and Eastern Europe: Transformation at the dawn of a new millennium (pp. 107-116). Praeger.

Georgievski, P. (2013). Sociologijata kako kritika na opštestvenata, obrazovnata i kulturnata promena. Matica makedonska.

Gzell, S. (2011). Międzynarodowe osiągnięcia polskiej urbanistyki. Kwartalnik Architektury i Urbanistyki, 56(3), 3-26.

Hetemi, A. (2020). Student movements for the Republic of Kosovo: 1968, 1981 and 1997. Palgrave Macmillan. https://doi.org/10.1007/978-3-030-54952-7

Home, R. (2007). Reconstructing Skopje, Macedonia, after the 1963 earthquake: The Master Plan forty years on. Papers in Land Management, 2007(7), 2-22.

Hudson, K. (2003). Breaking the South Slav dream: The rise and fall of Yugoslavia. Pluto Press.

Ivanoski, S. (1966). Sociološki istražuvanja: Rabotni i životni uslovi na železničarite od Makedonija. ŽTP.

Izveštaj od socijalniot pregled. (1965). Polservis - Zavod za urbanizam i arhitektura.

Jančeva, Lj., \& Litovski, A. (2017). Macedonia and Macedonians in Yugoslavia: In search for identity. In S. Biserko (Ed.), Yugoslavia from a historical perspective (pp. 163-185). Helsinki Committee for Human Rights in Serbia.

Janev, G. (2017). Burdensome past: Challenging the socialist heritage in Macedonia. Studia ethnologica Croatica, 29(1), 149-170. https://doi.org/10.17234/SEC.29.8

Jankowski, S. (1967). Plan ogólny Skopje. Miasto. Organ Towarzystwa Urbanistów Polskich 1967(4), 2-19.

Josifovski, I. \& al. (1988). Planiranjeto na semejstvoto vo SR Makedonija. NIP Studentski zbor. 
Jovanovski, J. (1976). Stanbenoto prašanje i standardot na domaḱinstvata korisnici na postojanata parična pomoš vo SR Makedonija. Godišnik na Institutot $z a$ sociološki i političko-pravni istražuvanja, 2(1), 99-122.

Jović, D. (2009). Yugoslavia: A state that withered away. Purdue University Press. https://doi.org/10.2307/j.ctt6wq3tg

Karłowicz, R., \& Pióro, Z. (1964). Problemy struktury miasta. Ośrodek Informacji Technicznej i Ekonomicznej w Budownictwie.

Kędziorek, A. (2014). The Museum of Modern Art in Skopje and the potentiality of an exhibition space. In $Ł$. Stanek (Ed.), Team 10 east: Revisionist architecture in real existing modernism (pp. 205-211). Museum of Modern Art in Warsaw.

Kočiški, I. (1983). Zavod za zaštita na spomenicite na kulturata na grad Skopje 1963-1983. Zavod.

Kostic, C. (1983). Sociology in Yugoslavia 1960-1970. International Review of Modern Sociology, 13(1-2), 375-395.

Kostovski, S. (1975). Sociologija na seloto. Godišnik na Institutot za sociološki i političkopravni istražuvanja, 1(1), 13-20.

Kulić, V. (2014). Building the non-aligned Babel: Babylon Hotel in Baghdad and mobile design in the global Cold War. ABE Journal, 2014(6), 1-33. https://doi.org/10.4000/abe.924

Ladinski, V. B. (1997). Post 1963 Skopje earthquake reconstruction: Long term effects. In A. A. Awotona (Ed.), Reconstruction after disaster: Issues and practices (pp. 73-107). Ashgate Publishing.

Lazić, M. (2011) Sociology in Yugoslavia: Correlation dynamics between critical and integrative social theory in liberal socialism. In U. Brunnbauer, C. Kraft, \& M. Schulze Wessel (Eds.), Sociology and ethnography in East-Central and South-East Europe: Scientific self-description in state socialist countries (pp. 87-106). Oldenbourg Verlag.

Le Normand, B. (2008). The modernist city reconsidered: Changing attitudes of social scientists and urban designers in 1960s Yugoslavia. Tokovi istorije, 2008(3-4), 141-159.

Le Normand, B. (2014). Designing Tito's capital: Urban planning, modernism and socialism. University of Pittsburgh Press. https://doi.org/10.2307/j.ctt7zwb9j

Limanovski, N., \& al. (1984). Makedonci muslimani. Kulturno naučni manifestacii na Makedoncite muslimani.

Lozanovska, M. (2012). Kenzo Tange's forgotten master plan for the reconstruction of Skopje. Fabrications, 22(2), 140-163.

https://doi.org/10.1080/10331867.2012.733159

Lozanovska, M. (2016). Performing equality: The exceptional story of Mimoza Nestorova-Tomić in the post-1963 earthquake reconstruction of Skopje. In M. Pepchinski \& M. Simon (Eds.), Ideological equals: Women architects in socialist Europe 1945-1989 (pp. 123-138). Routledge.

Lozanovska, M., \& Martek, I. (2019). Skopje Resurgent: The international confusions of post-earthquake planning, 1963-1967. Planning Perspectives, 34(3), 497-513. https://doi.org/10.1080/02665433.2018.1423636 
Luszniewicz, A. (1974). Koncepcja mierników poziomu życia ludności. In J. Danecki (Ed.), Społeczne aspekty rozwoju gospodarczego (pp. 205-222). Państwowe Wydawnictwo Naukowe.

Madik, M. (1963). Armijata i narodot vo razurnatoto Skopje. Narodna armija.

Malisz, B., \& Pióro, Z. (1960). Czego urbanistyka oczekuje od socjologii? In Z. Pióro (Ed.), Socjologia a planowanie urbanistyczne (pp. 4-11). Komitet Budownictwa, Urbanistyki i Architektury.

Martek, I., \& Lozanovska, M. (2018). Consciousness and amnesia: The reconstruction of Skopje considered through Actor Network Theory. Journal of Planning History, 17(3), 163-183. https://doi.org/10.1177/1538513216680229

Matkovski, A. (1964). Hronika za zemjotresot vo Skopje. Kultura.

Mattioli, F. (2020) Dark finance: Illiquidity and authoritarianism at the margins of Europe. Stanford University Press. https://doi.org/10.1515/9781503612945

Mijalkoviḱ, M., \& Urbanek, K. (2011). Skopje - svetsko kopile: Arhitekturata na podeleniot grad. Goten.

Milosavlevski, S., \& Tomovski, M. (1997). Albancite vo Republika Makedonija 19451995: Legislativa, politička dokumentacija, statistika. NIP Studentski zbor.

Mirchevska, K., \& Jancheva, L. (2013) Pomoshch' Sovetskogo Soiuza v vosstanovlenii Skop'e posle zemletriaseniia v 1963 g. In K.V. Nikiforov \& al. (Eds.), Rossiia (SSSR) i Makedoniia: Istoriia, politika, kul'tura 1944-1991 (pp. 113-120). RAN.

Mlinar, Z. (1979). Urbanizam i sociologija. Univerzitet u Beogradu, Arhitektonski Fakultet.

Mumford, E. (1992). CIAM urbanism after the Athens charter. Planning Perspectives, 7(4), 391-417. https://doi.org/10.1080/02665439208725757

Neofotistos, V. (2004). Beyond stereotypes: Violence and the porousness of ethnic boundaries in the Republic of Macedonia. History and Anthropology, 15(1), 1-36. https://doi.org/10.1080/027572004200191046

Nettmann-Multanowska, K., \& al. (2014). Tigers: The architecture of Jerzy Mokrzyński, Eugeniusz Wierzbicki and Wacław Kłyszewski. NI Museum of Contemporary Arts. https://issuu.com/polembskopje/docs/the_warsaw_tigers

Olszewski, J. (2013). Czas Po Prostu. Karta, 77(1), 102-115.

Olujić, D., \& Stojaković, K. (Eds.). (2012). Praxis: Društvena kritika i humanistički socijalizam. Roza Luxemburg Stiftung.

Osnoven urbanistički plan: Izveštaj pripremen za Obedinetite Nacii kako izvršna agencija na specijalniot Fond na Organizacijata na Obedinetite Nacii (1965). Polservis - Zavod za urbanizam i arhitektura.

Padgett, J. F. (1973). Philosophy and Social Planning in Yugoslavia. Social Theory and Practice, 2(4), 439-458. https://doi.org/10.5840/soctheorpract19732410

Pióro, Z. (1962). The social environment of two housing estates in Lublin, Poland. Ekistics, 14(84), 217-226.

Pióro, Z. (1964). Rodzina i mieszkanie we współczesnej kulturze. In J. Ziółkowski (Ed.), Urbanizacja a relacje społeczne wsi i miasta (pp. 137-163). Państwowe Wydawnictwo Naukowe. 
Pióro, Z. (1965). Theoretical principles and problems of the sociology of town planning. Ekistics, 19(110), 79-80.

Poposki, Z., \& Todorova, M. (2016). Public memory in post-conflict Skopje: Civic art as resistance to narratives of ethnicity and disintegration. In D. O'Rawe \&M.Phelan(Eds.), Post-conflictperformance, film and visual arts: Cities of memory (pp. 95-112). Palgrave Macmillan. https://doi.org/10.1057/978-1-137-43955-0_6

Popovski, J. (1983). Skopje 63/83. Partizanska knjiga; OOUR Izdavačko publicistička delatnost Beograd.

Popovski, V. (1976). Javnoto mislenje vo SR Makedonija 1976: Rezultati od Anketnog Ispituvanja. Institut za sociološki i političko-pravni istražuvanja pri Univerzitetot "Kiril i Metodij".

Poulton, H. (1995). Who are the Macedonians. Indiana University Press.

Radičeski, N. (2013). Liberalizmot vo Makedonija: 1966-1974. Makedonika litera.

Ramet, P. (1984). Nationalism and Federalism in Yugoslavia: 1963-1983. Indiana University Press.

Report on social survey. (1965). Polservice - ITPA.

Senior, D. (1970). Skopje Resurgent: The story of a United Nations special fund town planning project. United Nations.

Sennett, R. (2006, November). The Open City. Urban Age. https://urbanage.lsecities. net/essays/the-open-city

Sher, G. S. (1977). Praxis: Marxist criticism and dissent in socialist Yugoslavia. Indiana University Press.

Sierniński, W. (1984). Zygmunt Pióro (1916-1984). Studia Socjologiczne, 94(3), 5-8.

Skopje, 1963-1983. (1983). Redakciski odbor Večer.

Skopje, prostoren konept. (1965). Zavod za urbanizam i arhitektura.

Skopje, rezime na izveštajot za osnovniot urbanistički plan. (1965). Zavod za urbanizam i arhitektura.

Skopje, urbanistička studija-2. (1965). Zavod za urbanizam i arhitektura.

Skopje: Study of the Master Plan. (1964). Warsaw Council - Chief Architect of Warsaw - Town Planning Office - Skopje Team.

Sostojbi i ocenki na sostojbite vo oblasta na naučnoistražuvačkite dejnosti vo SRM i globalni nasoki na nivniot razvoj: Svodna studija. (1987). Ekonomski institut Skopje - Institut za sociološki i političko-pravni istražuvanja Skopje.

Spaskovska, Lj. (2011). Macedonia's nationals, minorities and refugees in the post-communist labyrinths of citizenship. CITSEE Working Paper Series, 2011(5), 1-27.

Spaskovska, Lj. (2018). Building a better world? Construction, labour mobility and the pursuit of collective self-reliance in the 'global South', 1950-1990. Labor History, 59(3), 331-351. https://doi.org/10.1080/0023656X.2018.1429185

Spaskovska, Lj. (2020). Constructing the 'City of International Solidarity': Non-aligned internationalism, the United Nations and visions of development, modernism and solidarity, 1955-1975. Journal of World History, 31(1), 137-163.

https://doi.org/10.1353/jwh.2020.0005 
Stamova, M. (2017). Albancite $v$ SR Makedonija prez poslednoto desetiletie $v$ Titova Jugoslavija (1981-1991). Ivan Sapundžiev.

Stanek, Ł. (2020). Architecture in global socialism: Eastern Europe, West Africa, and the Middle East in the Cold War. Princeton University Press. https://doi.org/10.1515/9780691194554

Stawowy-Kawka, I. (2014). Albańczycy w Macedonii 1944-2001. Wydawnictwo Uniwersytetu Jagiellońskiego.

Stefanovska, J., \& Koželj, J. (2012). Urban planning and transitional development issues: The case of Skopje, Macedonia. Urbani izziv, 23(1), 91-100.

Sufin, Z. (1964). Społeczność małych miast na tle procesów urbanizacji i uprzemysłowienia. Ruch Prawniczy, Ekonomiczny i Socjologiczny, 26(3), 209-224.

Sufin, Z. (1967). Studia socjologiczne. Miasto. Organ Towarzystwa Urbanistów Polskich 1967(4), 32-37.

Sufin, Z. (n.d.). Socjologiczne refleksje o problemach odradzającego się po trzęsieniu ziemi Skopje. [Unpublished manuscript].

Tange, K. (1971). Skopje city center reconstruction project. The Japan Architect, 178(September-October), 47-48.

Taševa, M., \& al. (1998). Etničkite grupi vo Makedonija: Sovremeni sostojbi. Filozofski fakultet - Skopje.

Tolic, I. (2017). Ernest Weissmann's World City: The reconstruction of Skopje within the Cold War context. Southeastern Europe, 41(2), 171-199. https://doi.org/10.1163/18763332-04102004

Tolic, I. (2019). The Skopje Urban Plan Project and Doxiadis Associates. In K. Amygdalou, K. Tsiambaos, \& C. Kritikos (Eds.), The future as a project: Doxiadis in Skopje (pp. 38-49). Hellenic Institute of Architecture.

Trajanovski, N. (2021a). Skopje 2014 reappraised: Debating a Memory Project in North Macedonia. In A. Milošević \& T. Trošt (Eds.), Europeanisation and memory politics in the Western Balkans (pp. 151-176). Palgrave Macmillan. https://doi.org/10.1007/978-3-030-54700-4_7

Trajanovski, N. (2021b). Skopje, the City of solidarity: A framework for interpreting the local memory of the 1963 Skopje earthquake. Journal of Nationalism, Memory \& Language Politics, 15(2), 30-51.

Trifunovski, J. (2019). Albanskoto naselenie vo Socijalistička Republika Makedonija: Antropološki i etnografski istražuvanja. Magor.

Tufli, M. (1978). Klasno rešenie na urbanoto prašanje. Godišnik na Institutot za sociološki i političko-pravni istražuvanja, 4(1), 183-201.

Uzunov, N. (1961). Faktori i metodi na industrijalizacijata. Kultura.

Uzunov, N. (1975). Empiriska analiza za vlijanieto na ekonomskite, socijalnite $i$ demografskite faktori vrz migracijata od selo vo grad vo SR Makedonija. Ekonomski fakultet.

Veljanovski, N. (2002). Makedonija 1945-1991: Državnost i nezavisnost. Institut za nacionalna istorija - Matica makedonska.

Veljanovski, P. (2019). The contribution of Polish urban planners and architects to the post-earthquake reconstruction of Skopje. In A. Wąsowska-Pawlik (Ed.), Skopje: 
City, architecture and art of solidarity (pp. 33-51). International Cultural Centre Gallery.

Véron, O. (2015). Deconstructing the divided city: Identity, power and space in Skopje. [Unpublished doctoral dissertation]. University College London.

Videkanić, B. (2020). Nonaligned modernism: Socialist postcolonial aesthetics in Yugoslavia, 1945-1985. McGill-Queen's University Press.

https://doi.org/10.2307/j.ctvxw3pdd

Vorríšek, M. (2012). The Reform Generation: 1960s Czechoslovak sociology from a comparative perspective. Kalich.

Wawryszuk, P. (2018). Normalization of Polish-Yugoslav relations after Wladysław Gomulka's return to power (1956-1958). Istorija 20. veka, 36(2), 139-154. https://doi.org/10.29362/ist20veka.2018.2.waw.139-154

Woodward, S. L. (1995). Socialist unemployment: The political economy of Yugoslavia 1945-1990. Princeton University Press. https://doi.org/10.1515/9780691219653

Wyporek, B. (2009). Daleko od Warszawy: Architekta zapiski z trzech kontynentów. Oficyna Wydawniczo-Poligraficzna.

Zátopek, A. (1968). The Skopje earthquake of 26 July 1963 and the seismicity of Macedonia. In Proceedings of the international seminar on earthquake engineering - Skopje 1964. Held under the auspices of the Federal Government of Yugoslavia and of Unesco: Skopje, 29 September to 2 October (pp. 77-80). UNESCO.

Ziółkowski, J. (1964). Socjologiczne aspekty urbanizacji w Europie niektóre problemy i kierunki badań. In J. Ziółkowski (Ed.), Urbanizacja a relacje społeczne wsi i miasta (pp. 3-22). Państwowe Wydawnictwo Naukowe.

Živković, M. (1975). Sociološka studija za generalni urbanistički plan Titograda: Prilog sociologiji stanovanja. Univerzitet u Beogradu, Arhitektonski Fakultet.

Živković, M. (1977). Neki sociološki aspekti planiranja. Univerzitet u Beogradu, Arhitektonski Fakultet.

Živković, M. (1979). Sociološki ogledi o gradu i stanovanju. Univerzitet u Beogradu, Arhitektonski Fakultet.

Živković, M. (1980). Prilog jugoslovenskoj urbanoj sociologiji. Zavod za organizaciju poslovanja i obrazovanje kadrova.

\section{Newspaper articles:}

Aceski, I. (1993, July 16). Pogrešna obnova. Večer.

Boczek, E. (1963, August 25). Tragedia miasta. Nowa Wieś. [Warszawa].

Čičak, R. (1969, December 22). Podelja vlasti u Sobranju. Vjesnik.

Crvenkovski, K. (1970, February 22). Progresivna angažiranost: Dvaesetipet godini of prviot broj na Birlik. Nova Makedonija.

Doberšek, T. (1973, June 2). Alarm v raju. Delo.

Dogramadžiev, Z. (1964, September 17). Graǵanine, kakov stan sakaš? Večer. 
Elimov, R. (1969, February 23). Novi makedonski rečnici. Nova Makedonija.

Eljasiak, J. (1963, August 18). Skopje żyje! Sztandar Młodych.

Fethke, E. (1963, August 25). Tam, gdzie czas stanął o 5.14 ... i gdzie życie zwyciężyło. Dookoła świata. [Warszawa].

Ilicz, D. (1963, August 27). Do Skopje wraca życie. Głos Pracy.

Institut za sociološki i pravni isleduvanja. (1964, July 2). Večer.

Janković, Dj. (1982, February 20). Četiri puta više Jugoslavena. Vjesnik.

Kočan, I. (1988, July 5). Rezultati najnovijeg ispitivanja javnog mnjenja u Makedoniji: Optimizam sa zadrškom. Večernje Novosti.

Konarz, M. (1963, August 18). Skopje: Dramat-życie. Ilustrowany magazyn studencki. [Warszawa].

Krste Crvenkovski: Savez Komunista ne može da ostvari istorijsku ulogu bez razvijene demokratije u sopstvenim redovima. (1966, September 29). Borba.

Lazarewicz, Ż. (1963, September 15). Pod ruinami Skopje. Kultura.

Marić, D. (1986, December 24). Mlaka idejna borba. Politika.

Milić, T., \& Krstić, M. (1988, December 19). Razgovor sa Mihailom Danevim, sektretarom Pretsedništva CK SK Makedonije: Predložene ustavne promene nisu dovoljne za izlaz iz krize. Politika.

Milić, T. (1988, November 27). Bespravna izgradnja s političkim posledicama. Politika.

Mozio, J. (1963, August 11). Tragedia miasta i ludzi. Gazeta Chłopska.

Neoričić, N. (1988, February 24). Vruča skopska čaršija. Reporter.

Padori, S. (1985, July 25). Za Skopje 82 zemji. Večer.

Paškovski, S., \& Stefanović, N. (1987, October 21). Levo i desno od Vardara. Večernje novosti.

Paškovski, S. (1983, February 16). Iz Sobranja Makedonije: Nedopustivo manipuliranje nacionalnim osećanjima. Borba.

Paškovski, S. (1988, November 16). Duško Georgijev, predsednik Komisije za medjunacionalne odnose, o peticiji albanskih intelektualaca sa Kosova: Tutorstvo samo maska. Večernje novosti.

Polscy projektanci opracują generalny plan Skopje. (1963, September 14). Życie Warszawy.

Popovski, J. (1968, March 2). Plenum CK SK Makedonije. Politika.

Robakowski, A. (1963, September 1). Przeżyłem trzęsienie ziemi w Skopje: Relacja polskiego inżyniera który oglądał to na własne oczy. Przekrój.

Simovič, D. (1963, August 11). Byłem tego świadkiem. Świat.

Strzelecka, W. (1963, August 1). Między życiem i śmiercią. Trybuna Ludu. 
Збор имаат граѓаните:

Првата социолошка студија, полската социолошка експертска помош во Македонија од средината на 1960-тите и постземјотресната историја на меѓуетнички односи во Скопје

Скопското утро од 26 јули 1963 година е моментот кога градот беше погоден од катастрофален земјотрес што резултираше со 1070 жртви, а уништи и две третини од градските објекти и инфраструктура. Политички неврзаната југословенска влада веднаш објави повик за помош на разурнатиот град, на којшто, пак, одговорија преку 80 држави ширум светот, Обединетите нации и други меѓународни организации. Овој голем одзив ги поттикна домашните власти да го преобмислат пост-земјотресно Скопје како „Град на солидарноста“ симбол на трансблоковската соработка - и „Отворен град“ - отворен за домашни миграции и миграции во рамки на Федерацијата, како и пример за сѐ-југословенската државотворна парола „братство и единство“. Сепак, растечките меѓуетнички тензии во 1980-тите, распадот на Југославија и конфликтот од 2001 година придонесоа за драматичен пресврт на јавната призма за пост-земјотресната обнова и демографските политики; наратив што беше особено промовиран преку мемориските политики во Македонија по 2001 година.

Овој труд се однесува на една прилично занемарена епизода од пост-земјотресната обнова на Скопје: првата социолошка студија од поголеми размери во градот, од декември 1964 година до април 1965 година, изведена како дел од полската експертска помош за постземјотресно Скопје и во рамки на подготовките за Генералниот план за Скопје, спонзорирани од страна на ОН. Иако објавената студија содржеше екслузивни резултати за економските и демографските услови во коишто живееја локалните домаќинства и преглед за некои од доминантните меѓуетнички проблеми во градот, студијата не го доби потребното вниманите од властите, а до распадот на Југославија беше занемарена и во научната литература. Па така, со цел да ги презентирам главните резултати од овој меѓудржавен проект, во овој труд ќ ја реконструирам предисторијата, теренското истражување и првичните резултати на социолошката студија преку триангулација на архивски материјали, полуструктурирани интервјуа со полските и македонски истражувачи ангажирани за работата на студијата и секундарна литература за скопската урбана обнова. Конечно, заклучувам дека студијата - нејзината реализација, резултати и 
последователни толкувања - може да се чита како клуч за подобро разбирање на пост-земјотресната историја на Скопје и меѓуетничките односи во градот.

Клучни зборови: Скопје, скопскиот земјотрес од 1963 година, социологија на град, градско планирање, меѓуетнички односи, трансфери на знаење.

\section{Obywatele mają głos:}

Pierwsze studium socjologiczne, polska socjologiczna pomoc ekspercka w Macedonii w połowie lat 60. XX wieku i historia stosunków międzyetnicznych w Skopje po trzęsieniu ziemi

Poranek w Skopje 26 lipca 1963 roku był momentem, kiedy miasto zostało dotknie katastrofalnym trzęsieniem ziemi, które przyniosło 1070 ofiar [wśród mieszkańców - JS], i zniszczyło dwie trzecie miasta. Należąca do bloku państw niezaangażowanych Jugosławia natychmiast poprosiła o pomoc dla zrujnowanego miasta, na którą odpowiedziało 80 państw z całego świata, z Organizacji Narodów Zjednoczonych i z innych organizacji międzynarodowych. Tak masowa reakcja [ze strony świata] zainspirowała miejscowe władze do wymyślenia [na nowo] Skopje po trzęsieniu ziemi jako „miasta solidarności" - symbolu współpracy ponad podziałami na bloki [polityczne] i "miasta otwartego" na migrację wewnętrzną [w ramach republiki] i w ramach Federacji [jugosłowiańskiej], wreszcie jako przykład [realizacji] ogólnojugosłowiańskiego państwowotwórczego hasła „braterstwo i jedność". Jednakże rosnące od lat 80 . XX wieku napięcia międzyetniczne, rozpad Jugosławii i konflikt z 2001 roku przyniosły dramatyczny zwrot na płaszczyźnie oficjalnej $\mathrm{w}$ kwestii odnowy [miasta] po trzęsieniu ziemi i w stosunku do polityki demograficznej. Ta narracja była szczególnie promowana poprzez praktyki upamiętniania w Macedonii po 2001 roku.

Niniejszy artykuł zajmuje się całkiem zapomnianym epizodem z czasów przebudowy Skopje po trzęsieniu ziemi: [przedmiotem analizy będzie] pierwsze większe socjologiczne opracowanie obejmujące okres od grudnia 1964 do kwietnia 1965, które jest częścią polskiej pomocy eksperckiej dla Skopje po trzęsieniu ziemi w ramach przygotowań do tzw. planu generalnego dla miasta, finansowanego przez ONZ. Pomimo, że opublikowane studium zawiera wyjątkowe dane co do ekonomicznego i demograficznego poziomu życia miejscowych gospodarstw domowych i przegląd najważniejszych problemów międzyetnicznych w mieście, nie zyskało koniecznej uwagi ze strony władz, a do rozpadu Jugosławii nie było zauważane tak- 
że w literaturze naukowej. Celem mojego artykułu jest zatem prezentacja głównych wyników badań tego międzynarodowego projektu, rekonstrukcja badań terenowych i pierwszych rezultatów socjologicznych [wywiadów] przy zastosowaniu metody triangulacyjnej [korzystającej z wielu technik badawczych]: analizy materiałów archiwalnych, nieustrukturyzowanych wywiadów z polskimi i macedońskimi badaczami zaangażowanymi w pracę nad projektem, opracowań dotyczących odnowy tkanki miejskiej Skopje. W konkluzji dowodzę, że opracowanie - jego realizacja, wyniki i prognozy - można czytać jako klucz do lepszego zrozumienia stosunków etnicznych i historii Skopje po trzęsieniu ziemi.

Słowa kluczowe: Skopje, trzęsienie ziemi w Skopje w 1963 roku, socjologia miasta, planowanie miasta, stosunki etniczne, transfer wiedzy.

Przekład z języka macedońskiego Jolanta Sujecka

\section{Note}

Naum Trajanovski, Graduate School for Social Research, Polish Academy of Sciences, Warsaw

trajanovskinaum@gmail.com

https://orcid.org/0000-0001-9686-7861

This research was supported by the National Science Centre, Poland under the PRELUDIUM 17 grant scheme, contract number 2019/33/N/HS3/02209.

No competing interests have been declared.

\section{Publication History}

Received: 2021-05-27; Accepted: 2021-09-03; Published: 2021-12-20 